\title{
EFFECT OF SKIPPING ONE IRRIGATION DURING DIFFERENT GROWTH STAGES AND FOLIAR APPLICATION OF MICRONUTRIENTS ON ROSELLE (HIBISCUS SABDARIFFA, L.) PLANTS AND SOME WATER RELATIONS IN HEAVY CLAY SOILS
}

\author{
Nahed, M. Rashed* and E.A. Moursi ** \\ * Department of Medicinal and Aromatic Plants, Agric. Res. \\ Center, Giza, Egypt. ** Soils, Water and Environment Res. Inst., \\ Agric. Res. Center, Giza, Egypt.
}

\begin{abstract}
Water considers the most important component of life, it is rapidly becoming a critically short commodity for humans and crop production. Drought is one of the major a biotic stresses in agriculture worldwide. In order to study the effect of water stress (skipping one irrigation at vegetative, flowering and fruits formation growth stages) in comparison with traditional irrigation in addition to foliar application of chelated iron, zinc, manganese and their combination on growth, productivity of dark roselle (Hibiscus sabdariffa, L.) plants and some water relations under surface irrigation system. Two field experiments were conducted at the Experimental Farm of Sakha Horticulture Research Station, Kafr El-Sheikh Governorate during the summer seasons of 2014 and 2015. The results revealed that skipping one irrigation at any of the three studied stages significantly reduced all the tested growth parameters and yield production as compared with unstressed plants (control). However, subjecting roselle plants to water stress at flowering stage had the most negative effect on growth parameters and yield production. On the other hand, water stress had a stimulating effect on chemical composition (total anthocyanin, T.S.S, acidity\%, pH and T.S.S acidity ratio). The present study also indicated that foliar application of chelated $\mathrm{Fe}, \mathrm{Zn}, \mathrm{Mn}$ and combination among them had a positive effect on growth parameters, yield and chemical composition but chelated $\mathrm{Zn}$ application surpassed the other nutrients in counteracted the deleterious effects of stress on chemical composition. Application of chelated $\mathrm{Fe}+\mathrm{Zn}+\mathrm{Mn}$ showed the significant increasing in calyxes yield/fed, fibers yield/fed and seeds yield/fed. Also, the highest overall mean values for seasonal amount of water applied, consumptive use, water productivity and productivity of irrigation water for all plant organs were recorded under traditional irrigation. Meanwhile, the lowest overall mean values were recorded under water stress treatments and the amount of water saving is $8.89 \%$. Concerning, micronutrients as foliar application, the highest overall mean values were recorded under application of chelated $(\mathrm{Fe}+\mathrm{Zn}+\mathrm{Mn})$ in comparison with non-application and application every nutrient as alone. Regarding, consumptive use efficiency, the highest mean values were recorded under skipping one irrigation at vegetative growth
\end{abstract}


stage, but the lowest were recorded under traditional irrigation. Also, the highest values were recorded under foliar application treatment $(\mathrm{Fe}+\mathrm{Zn}+\mathrm{Mn})$ comparing with non- application and application every nutrient as alone. This study can be concluded that skipping one irrigation at vegetative growth stage when cultivated roselle plants under studying region with chelated ( $\mathrm{Fe}+\mathrm{Zn}+$ $\mathrm{Mn}$ ) foliar application which counteracted the deleterious effects of stress and chelated $\mathrm{Zn}$ foliar application only to increase chemical component .Nevertheless, reduction in yield offset saving nearly $9 \%$ of water applied.

Key wards: roselle, water stress, iron, zinc ,manganese, foliar
application Corresponding Author: E-mail: rashed_nahed @yahoo.com

\section{INTRODUCTION}

Roselle, Hibiscus sabdariffa, $L$ (Karkadeih) is an annual or perennial bushy sub shrub, about 5-8 feet height, with branched, erect, smooth and often purplish stem, belonging to Family Malvaceae. This plant is indigenous to tropic Africa (Kirby, 1963). It is widely cultivated in Egypt, China and Thailand for different purposes. The plant parts including seeds, leaves, fruits and roots are used in various foods such as wine, juice, jam, jelly, syrup gelatin, pudding, cake, ice cream, tea, spice and other desserts. roselle is a good source of natural antioxidants (protocatechuic acid and anthocyanins) that protect the body from damage by free radicals and lipid. (Ali et al., 2005). It is used for the treatment of several ailments, including high blood pressure, liver diseases, fever, urinary tract infection, pain of the muscles of the uterus and intestine (Herrera-Arellano et al., 2004). Environmental stresses such as water and nutrition deficiency are the most important factors that limit plant growth and productivity in arid and semi-arid regions. Most of agricultural areas in the world suffer from low water supply and irTraditional distribution of rainfall during the growing season, so some resident crops and cultivars are used. Drought tolerance can be defined as the ability of plants to grow sufficiently and produce high yield even when exposed to water stress (Bagci et al., 2007). Due to drought and competing water demands in Egypt have put enormous pressure on irrigation water. Conserve both the quality and quantity of water appropriate strategies will have to be developed to avoid the risk of future water supplies. Reducing irrigation water is to employ practices that improve water productivity (crop yield per unit volume of water used) Maheshwari and Grewal (2009). However, the world population is expanding rapidly and is expected to be around 8 billion by the year 2025 (Pinstrup-Andersen et al., 1999) It affects nearly all the plant growth processes. However, the stress response upon the intensity, rate and duration of exposure and the 
stage of crop growth (Wajid, et al 2004). Identification of the critical irrigation timing and scheduling of irrigation based on a timely and accurate basis to the crop is the key to conserving water and improving irrigation performance and sustainability of irrigated agriculture (Ngouajio et al., 2007)

Increasing crop tolerance to water limitation would be the most economical approach to enhance productivity and reduce agricultural use of fresh water resources (Gao,et al 2008).When considering a watering regime for a crop, it is wise to understand the sensitive growth stages for water stress and the water requirements of the crop in order to achieve maximum yield and maintaining adequate soil moisture conditions during moisture-sensitive stages of growth, so irrigation water may be saved if soil water(Thalooth, et al.2006). Abiotic stress especially Water stress represents an oxidative stress and kills plants by inducing production of ROS, especially during photosynthesis and enzyme activity ( Hajlaoui, et al., 2010). Currently, foliar-applied nutrients have limited direct use for enhancement of stress resistance mechanisms in field crops. Nevertheless, the interactions between plant nutrient levels and stress repair mechanisms are now being studied (Lavon, et al 1999). Micronutrients spraying led to increasing macro and micronutrients uptake as a result of improving root growth which consequently led to greater absorbing surface (Abdalla et al., 1992). Zinc ( $\mathrm{Zn}$ ), iron (Fe) and manganese $(\mathrm{Mn})$ deficiency are common nutrient problem in crop production in arid and semi-arid regions where always soil $\mathrm{pH}$ is high and organic matter is low (Hajlaoui et al., 2010). Some reports suggest that the secondary metabolites of medicinal plants can be improved by foliar application of micronutrients (Zehtab-Salmasi et al, 2008). In the cited literature, no works on the effects of water stress on roselle plants under Northern Middle Nile Delta region conditions were found. Therefore, the objectives of this work were undertaken to evaluate the efficiency of foliar application with iron, zinc, manganese and their combinations to the harmful effect of skipping one irrigation at different growth stages on growth, yield and some water relations of roselle plants.

\section{MATERIALS AND METHODS}

Two field experiments were performed at the Experimental Farm of Sakha Agricultural Research Station, Kafr El-Sheikh Governorate. The experimental site is located at Sakha $31-07^{\prime} \mathrm{N}$ Latitude, $30-57^{\prime} \mathrm{E}$ Longitude, with an elevation of about 6 metres above mean sea level. 
This location is representative of conditions in the Northern Middle Nile Delta region during the two successive summer growing seasons of 2014 and 2015 to study the effect of water stress (skipping one irrigation at vegetative, flowering and fruits formation growth stages) in addition to traditional irrigation and foliar application of chelated (iron , zinc, manganese and $\mathrm{Fe}+\mathrm{Zn}+\mathrm{Mn}$ ) on growth, yield, chemical composition and some water relations on dark roselle (Hibiscus sabdariffa , L.) plants under surface irrigation system. Seeds of roselle were obtained from Medicinal and Aromatic plants Department, ARC, Egypt and were sown in the field on May $10^{\text {th }}$ and $18^{\text {th }}$ in the first and second seasons, respectively. The seeds were planted in hills at 30 $\mathrm{cm}$ distance on rows $60 \mathrm{~cm}$ apart in plot. The irrigation area is $123.2 \mathrm{~m}^{2}$ (5.6m width $\times 22 \mathrm{~m}$ length) and the irrigated plots were isolated by ditcher of $1.5 \mathrm{~m}$ in width to avoid lateral movement of water. The area of micronutrients foliar application was $22.4 \mathrm{~m}^{2}(5.6 \mathrm{~m}$ width $\times 4 \mathrm{~m}$ length). The physical and chemical properties of the experimental site were determined before cultivation, as shown in Tables (A and B). Soil samples from different depths at the experimental site were collected at each $15 \mathrm{~cm}$, soil depth up to $60 \mathrm{~cm}$ and analyzed for some physical properties Table(A) particle size distribution was determined according to the international method Klute, (1986). Soil field capacity (FC\%), Permanent wilting point (PWP\%), soil available water (AW\%) were determined according to James (1988), Soil bulk density $\left(\mathrm{Bd}, \mathrm{Mg} / \mathrm{m}^{3}\right.$ ) were determined according to Klute, (1986) .Other soil samples were also collected from the same experimental site for each $15 \mathrm{~cm}$, soil depth up to $60 \mathrm{~cm}$ and analyzed for some chemical properties ,Table(B) shown total soluble salts(soil ,EC), soil reaction $(\mathrm{pH})$ both soluble cations and anions were determined according to Jackson (1973).While, $\mathrm{SO}_{4}^{--}$was calculated by the difference between cations and anions .

Table A: The mean values of some physical properties of the experimental site before cultivation of roselle Hibiscus sabdariffa, L. in the two growing seasons (2014-2015)

\begin{tabular}{|c|c|c|c|c|c|c|c|c|c|}
\hline \multirow{2}{*}{ Soil depth $(\mathrm{cm}$.) } & \multicolumn{3}{|c|}{ Particle size distribution } & \multirow{2}{*}{\begin{tabular}{|l} 
Texture \\
Class \\
\end{tabular}} & \multirow{2}{*}{ F.C \% } & \multirow{2}{*}{ PWP \% } & \multirow{2}{*}{$\mathrm{Bd} \mathrm{Mg} / \mathrm{m}$} & \multirow{2}{*}{ AW\% } & \multirow{2}{*}{$\begin{array}{c}\text { Total } \\
\text { porosity } \%\end{array}$} \\
\hline & sand \% & Silt\% & Clay \% & & & & & & \\
\hline $0-15$ & 12.30 & 33.30 & 54.40 & Clayey & 46.90 & 25.49 & 1.08 & 21.41 & 59.25 \\
\hline $15-30$ & 20.20 & 34.20 & 45.60 & Clayey & 39.72 & 21.49 & 1.12 & 18.23 & 57.74 \\
\hline $30-45$ & 20.40 & 41.40 & 38.20 & Clayey & 38.00 & 20.65 & 1.17 & 17.35 & 55.85 \\
\hline $45-60$ & 21.10 & 41.50 & 37.40 & Clayey & 35.48 & 19.28 & 1.22 & 16.20 & 53.96 \\
\hline Mean & 18.50 & 37.60 & 43.92 & Clayey & 40.03 & 21.76 & 1.15 & 18.27 & 56.60 \\
\hline
\end{tabular}

Total porosity $(\%)=\frac{\text { Real density }- \text { Bulk density }}{\text { Real density }} \times 100$

Real density in mineral soils $=2.65 \mathrm{Mg} / \mathrm{m}^{3}$ 
Table B: The mean values of some chemical properties of the experimental site before cultivation of roselle Hibiscus sabdariffa, $L$. in the two growing seasons (2014-2015)

\begin{tabular}{|c|c|c|c|c|c|c|c|c|c|c|}
\hline \multirow{2}{*}{$\begin{array}{c}\text { Soil } \\
\text { depth, cm }\end{array}$} & \multirow{2}{*}{$\begin{array}{c}E C \mathrm{ds} / \mathrm{m} \\
\text { at } 25 \mathrm{C}\end{array}$} & \multirow{2}{*}{$\begin{array}{c}\text { PH } \\
1: 2: 5 \text { soil water } \\
\text { suspension }\end{array}$} & \multicolumn{4}{|c|}{ Cations meq/l } & \multicolumn{3}{|c|}{ Anions meq } & $\pi$ \\
\hline & & & $\mathrm{Ca}^{++}$ & $\mathrm{Mg}^{++}$ & $\mathrm{Na}^{+}$ & $\mathrm{K}^{+}$ & $\mathrm{CO}_{3}^{--}$ & $\mathrm{HCO}_{3}^{-}$ & $\mathrm{Cl}^{-}$ & $\mathrm{SO}_{4}^{--}$ \\
\hline $0-15$ & 3.86 & 8.55 & 14.80 & 9.68 & 13.71 & 0.41 & 0.0 & 4.50 & 15.00 & 19.10 \\
\hline $15-30$ & 4.38 & 8.46 & 17.76 & 9.60 & 15.97 & 0.47 & 0.0 & 4.00 & 16.00 & 23.80 \\
\hline $30-45$ & 4.49 & 8.47 & 20.72 & 9.20 & 14.55 & 0.43 & 0.0 & 4.00 & 12.00 & 28.90 \\
\hline $45-60$ & 4.83 & 8.45 & 14.80 & 19.80 & 13.28 & 0.42 & 0.0 & 4.00 & 16.00 & 28.30 \\
\hline Mean & 4.39 & 8.48 & 17.02 & 14.07 & 14.38 & 0.43 & 0.0 & 4.13 & 14.75 & 25.03 \\
\hline
\end{tabular}

$\mathrm{SO}_{4}{ }^{-1}$ was estimated by difference

\section{Meteorological conditions:}

Meteorological conditions during the two experimental growing seasons (2014 and 2015) for Sakha area are presented in Table (C)

Table C: Mean of some meteorological data at Kafr El-Sheikh area during the two growing seasons of 2014 and 2015

\begin{tabular}{|c|c|c|c|c|c|c|c|c|c|}
\hline \multirow{2}{*}{ Months } & \multicolumn{3}{|c|}{$T\left(c^{\circ}\right)$} & \multicolumn{3}{|c|}{$\mathrm{RH}(\%)$} & \multirow{2}{*}{$\begin{array}{c}\text { Ws } \\
\mathrm{m} / \mathrm{sec} \\
\text { at } 2 \mathrm{~m} \\
\text { height }\end{array}$} & \multirow{2}{*}{$\begin{array}{c}\text { Pan } \\
\text { Evap. } \\
(\mathrm{mm} / \mathrm{da} \\
\mathrm{y})\end{array}$} & \multirow{2}{*}{$\begin{array}{c}\text { Rain } \\
\mathrm{mm}\end{array}$} \\
\hline & Max. & Min. & Mean & Max. & Min. & Mean & & & \\
\hline \multicolumn{10}{|c|}{2014} \\
\hline May & 30.47 & 19.57 & 25.02 & 77.20 & $48.60^{\circ}$ & 62.90 & 1.14 & 5.87 & --- \\
\hline June & 32.65 & 20.6 & 26.63 & 86.23 & 52.30 & 69.27 & 0.95 & 6.56 & $\overline{0.00}$ \\
\hline July & 33.15 & 23.64 & 28.40 & 83.19 & 55.11 & 69.15 & 1.13 & 7.73 & 0.00 \\
\hline Agus & 34.10 & 21.80 & 27.95 & 92.40 & 53.50 & 72.95 & 1.15 & 8.14 & 0.00 \\
\hline Sep. & 32.49 & 20.76 & 26.63 & 87.57 & 52.20 & 69.89 & 1.03 & 6.65 & 0.00 \\
\hline Oct. & 29.75 & 18.75 & 24.25 & 80.92 & 53.39 & 67.16 & 0.95 & 4.51 & 0.00 \\
\hline Nov. & $\begin{array}{l}24.30 \\
\end{array}$ & 13.79 & 19.05 & 87.80 & 60.50 & 74.15 & 0.78 & 2.77 & 24.6 \\
\hline \multicolumn{10}{|c|}{2015} \\
\hline May & 30.19 & 18.79 & 24.49 & 77.3 & 46.1 & 61.7 & 1.33 & 7.15 & 0.00 \\
\hline June & 30.85 & 21.4 & 26.13 & $\begin{array}{ll}78.8 \\
\end{array}$ & 51.2 & 65.0 & 1.22 & 6.95 & 0.00 \\
\hline July & 33.0 & 22.4 & 27.7 & 85.2 & 54.3 & 69.8 & 1.13 & 6.86 & $\overline{0.00}$ \\
\hline Agus. & 35.1 & 25.0 & 30.1 & 83.8 & 51.7 & 67.8 & 1.06 & 8.15 & 0.00 \\
\hline Sep. & 34.6 & 23.8 & 29.2 & 82.7 & 46.5 & 64.6 & 1.14 & 6.64 & 0.00 \\
\hline Oct. & 29.9 & 20.6 & 25.3 & 80.9 & 54.1 & 67.5 & 1.01 & 4.53 & 65.9 \\
\hline Nov. & 24.4 & 14.42 & $\begin{array}{l}19.4 \\
\end{array}$ & $\begin{array}{l}87.0 \\
\end{array}$ & 64.2 & 75.6 & 0.81 & 3.19 & 52.4 \\
\hline
\end{tabular}

* Source: Meteorological Station at Sakha 31-07' N Latitude, 30-57'E Longitude with an. Elevation of about 6 metres above mean sea level.

The experimental design was split plot design, with four replications. The treatments were:

\section{A- Main treatments :( irrigation, I)}

$\mathrm{I}_{0}$ : control treatment (traditional irrigation like practice by local farmers in the studied area ) 
$I_{1}$ : skipping one irrigation at the vegetative growth stage,

$\mathbf{I}_{2}$ : skipping one irrigation at the flowering growth stage and

$I_{3}$ : skipping one irrigation at the fruits formation growth stage.

\section{B-Sub treatments: micronutrients foliar application}

1- Spraying with tap water (check treatment) 2- Spraying with chelated $\mathrm{Fe}$

3- Spraying with chelated $\mathrm{Zn}$

4- Spraying with

chelated Mn

5- Spraying with chelated $\mathrm{Fe}+\mathrm{Zn}+\mathrm{Mn}$

Micronutrients fertilizers ( $\mathrm{Fe}, \mathrm{Zn}$ and $\mathrm{Mn}$ ) at the concentration of $(250,200$ and $200 \mathrm{~g} / \mathrm{fed})$, respectively were obtained from Soil Fertility and Plant Nutrition Department, Sakha. Agric. Res .Station. These doses were splitted into three equal doses, one after 45 days from planting, one at the starting of flowering and the third one after two weeks later.

Mineral fertilization at the recommended dose of $75 \mathrm{~kg} \mathrm{~N} / \mathrm{fed}$ in form of Urea $(46.5 \% \mathrm{~N})$ was splitted into two equal doses, the first dose was added after one month from planting, the second dose was added after the first dose with one month and half of $100 \mathrm{~kg} \mathrm{~K} / \mathrm{fed}$ in form of potassium sulfate $\left(48 \% \mathrm{~K}_{2} \mathrm{O}\right)$ was added as one dose with the first dose of nitrogen application and $150 \mathrm{~kg}$ calcium superphosphate $\left(15.5 \% \mathrm{P}_{2} \mathrm{O}_{5}\right)$ per fed was added during soil preparation.

Roselle plants were harvested on $9^{\text {th }}$ and $14^{\text {th }}$ November in both seasons, respectively. The following data were recorded per plant

\section{A. Vegetative and flowering growth characters:}

1. Plant height $(\mathrm{cm})$.

2. Number of main branches/plant (effective tillers).

3. Number of fruits/plant

4. Weight of 1000 seeds $(\mathrm{g})$

5. Fresh and dry weight of fruits (g/plant).

B. Yield characters :( fiber, calyxes and seeds)

1. Fresh and dry weight of calyxes $\mathrm{g} /$ plant.

2. Calyxes yield $\mathrm{kg} / \mathrm{fed}$.

4. Dry weight of the aerial parts of plant without fruits (fiber yield ton/fed).

5. Seeds yield/plant

6. Seeds yield/fed 


\section{Chemical analysis:}

1. Total Anthocyanin Content $(\mathrm{mg} / 100 \mathrm{~g})$ : was determined calorimetrically according to the procedure described by $\mathrm{Du}$ and Francis (1973).

2. Total soluble solids (T.S.S): was measured by a hand refract meter according to method out lined in A.O.A.C. (2005).

3. Acidity\%: titratable acidity were determined according to standard method as described by Kirk and Sawyer, 1997

4. The $\mathrm{pH}$ values: were measured by $\mathrm{pH}$-meter

5. Total soluble solids (T. S. S) acidity ratio= calculated as T. S. S /acidity

\section{Water relations:}

1. Amount of irrigation water applied (Wa, $\mathrm{cm}$ and $\mathrm{m}^{3} / \mathrm{fed}$ ).

Amount of irrigation water applied was measured for each irrigation treatment and then seasonal water applied was recorded by using cutthroat flume $\left(30^{*} 90 \mathrm{~cm}\right)$ through the whole growing season and calculated as $\mathrm{m}^{3} / \mathrm{fed}$ according to Early (1975)

\section{Water consumptive use (CU, $\mathrm{cm}$ and $\mathrm{m}^{3} / \mathrm{fed}$ ).}

To compute the actual consumed water of the growing plants, soil moisture percentage was determined (on weight basis) before and after each irrigation as well as at harvesting. Soil samples were taken from successive layers in the effective root zone $(0-15,15-30,30-45$ and $45-60 \mathrm{~cm})$. This is a direct method for calculating water consumptive use by growing plants based on soil moisture depletion (SMD) or actual crop water consumed (ETC) according to Hansen et al. (1979).

$$
\mathrm{CU}=\mathrm{SMD}=\sum_{\mathrm{i}=1}^{\mathrm{i}=4} \frac{\phi_{2}-\phi_{1}}{100} * \mathrm{Dbi} * \mathrm{Di} * 4200
$$

Where

CU: Water consumptive use ( $\mathrm{Cu}, \mathrm{m}^{3} / \mathrm{fed}$.) in the effective root zone $(60$ $\mathrm{cm}$ ),

$\phi_{2}$ : Gravimetric soil moisture percentage 48 hours after irrigation,

$\phi 1$ : Gravimetric soil moisture percentage before the next irrigation,

Dbi: Soil bulk density $\left(\mathrm{Mg} / \mathrm{m}^{3}\right)$ for depth.

Di: Soil layer depth $(15 \mathrm{~cm})$ and

1: Number of soil layers (1-4)

$4200=$ Fadden area $\mathrm{m}^{2}$

\section{3- Consumptive use efficiency (Ecu \%)}

Values of consumptive use efficiency were calculated according to Doorenbos and Pruitt(1975)

$$
\text { Ecu\% }=\mathrm{CU} / \mathrm{Wa} * 100
$$


Ecu $=$ Consumptive use efficiency (\%): CU=water consumptive use $\left(\mathrm{m}^{3} / \mathrm{fed}\right)$

$\mathrm{Wa}=$ irrigation water applied to the field $\left(\mathrm{m}^{3} / \mathrm{fed}\right)$

4- Water productivity (WP, $\mathrm{kg} / \mathrm{m}^{3}$ )

Water productivity is generally defined as crop yield per cubic meter of water consumptive. Concept of water productivity in agricultural production systems is focused on producing more food with the same water resources or producing the same amount of food with less water resources .It was calculated according to Ali et al, 2007.

$$
\mathrm{WP}=\mathrm{Y} / \mathrm{CU}
$$

Where: $W P=$ water productivity (Kilogram fibers, seeds and calyxes $/ \mathrm{m}^{3}$ )

$Y=$ Dry weight of the aerial parts of plant without fruits (fiber yield), calyxes yield $\mathrm{Kg} / \mathrm{fed}$, seeds yield and for whole plant.

$\mathrm{CU}=$ Water consumptive use $\left(\mathrm{m}^{3} / \mathrm{fed}\right)$

\section{5- Productivity of irrigation water (PIW, $\mathrm{kg} / \mathrm{m}^{3}$ )}

Productivity of irrigation water was calculated according to Ali et al (2007).

$$
\mathrm{PIW}=\mathrm{Y} / \mathrm{Wa}
$$

Where: $Y=$ Dry weight of the aerial parts of plant without fruits (fiber yield), calyxes yield $\mathrm{Kg} / \mathrm{fed}$, seeds yield and for whole plant.

$\mathrm{Wa}=$ irrigation water applied $\left(\mathrm{m}^{3} / \mathrm{fed}\right)$

Data of both seasons were tabulated and statistically analyzed according to procedure described by Steel and Torrie (1980). L.S.D. test was used to compare the average means or treatments using COSTAT computer program.

\section{RESULTS AND DISCUSSION}

Effect of irrigation treatments and some micronutrients foliar application on growth: The growth characters as affected by irrigation treatments and foliar application of the different micronutrients are presented in Table (1). However, all growth parameters i.e. plant height, number of main branches, weight of 1000 seeds, number of fruits/plant as well as fresh and dry weight of fruits /plant were significantly reduced by skipping one irrigation at the different stages of growth as compared with the control plants in the two seasons .The magnitudes of reduction differed from character to another according to the growth stage. However, subjecting plants to water stress at flowering stage caused the highest reduction in all growth parameters in the two seasons. The adverse effect of drought stress on growth roselle parameter may be attributed to the decrease in net photosynthetic rates (photo inhibition) in Plants due to stomatal closure, which decreases or prevents water loss but reduces $\mathrm{CO}_{2}$ availability for chloroplast, Bertamini, et al (2007). These results were 
agreed with those reported by El- Boraie et al. (2009) on roselle plant. Water deficit decreased the growth rate, stem elongation and leaf expansion. Moreover, under the water stress conditions, IAAandGA3 decrease while ABA increases in different plants, Shao et al. (2007). Cell division and cell enlargement were inhibited leading to a reduction of growth which drought stress influences the normal physiology and growth of plants in many ways. Waraich et al (2011)

Foliar application of the different micronutrients results in Table (1) revealed also that foliar application of chelated $\mathrm{Fe}, \mathrm{Zn}, \mathrm{Mn}$ and the combination between them significantly increased all growth parameters in the two seasons .Spraying with chelated ( $\mathrm{Fe}+\mathrm{Zn}+$ $\mathrm{Mn}$ ) was superior in all features i.e. plant height, number of main branches ,weight of 1000 seeds, number of fruits/plant, fresh and dry weight of fruits / plant followed by Mn treatment as comparing with the control .These results coincide with those obtained by Kassab (2005) Thalooth et al (2006) and El-Fouly, et al. (2011), It can be concluded also that the enhancement effect of spraying roselle by $\mathrm{Fe}, \mathrm{Zn}, \mathrm{Mn}$ and the combination between them on growth parameters was very clear ,hence treated plants resulted in taller plants, greater number and weight of plant and fruits/plant .Such enhancement effect might be attributed to the favorable influence of these nutrients on metabolism and biological activity and its stimulating effect on photosynthetic pigments and enzyme activity which in turn encourage vegetative growth of plants (Cakmak, 2000). The interaction between irrigation treatment and foliar application of the different nutrients significantly affected all the studied growth parameters. However, foliar application of $(\mathrm{Fe}+\mathrm{Zn}+\mathrm{Mn})$ recorded the highest values for all growth parameters under normal irrigation treatment (control) in the two seasons .On the other hand, skipping one irrigation at flowering stage of growth $\mathrm{x}$ foliar application of distilled water treatment gave the lowest values for all growth characters. Similar results were obtained by Babaeian et al (2011). Such differences might be due to the $\mathrm{Fe}$ plays a key role in chlorophyll synthesis. In addition, iron enters in many plant enzymes that play dominant roles in oxidoredox reactions of photosynthesis and respiration (Curie and Briat, 2003). The superiority of $\mathrm{Mn}$ treatment resulted from the fact that manganese $(\mathrm{Mn})$, is regarded as an activator of many different enzymatic reactions and takes part in photosynthesis Manganese activates decarboxylase and dehydrogenase and is a constituent of complex PSII protein , SOD and phosphatase. Deficiency of Mn induces inhibition of growth chlorosis and necrosis, early leaf fall and low reutilization (Sajedi et al., 2009). 
Table 1: Effect of skipping one irrigation and foliar application of some micronutrients on plant height, number of main branches(effective tillers), dry weight of the aerial parts of plant without fruits, number of fruits, fresh weight of fruits /plant and dry weight of fruits /plant of roselle plants in $2014-2015$ seasons

\begin{tabular}{|c|c|c|c|c|c|c|c|c|c|c|c|c|c|}
\hline \multirow{2}{*}{$\begin{array}{l}\text { Irrigation } \\
\text { Treatment } \\
\text { s }\end{array}$} & \multirow[t]{2}{*}{$\begin{array}{c}\text { Foliar } \\
\text { application }\end{array}$} & \multicolumn{2}{|c|}{ Plant height(cm) } & \multicolumn{2}{|c|}{$\begin{array}{c}\text { Number of main } \\
\text { branches(effectiv } \\
\text { e tillers) }\end{array}$} & \multicolumn{2}{|c|}{$\begin{array}{l}\text { Dry weight of the } \\
\text { aerial parts of } \\
\text { plant without } \\
\text { fruits Ton/fed }\end{array}$} & \multicolumn{2}{|c|}{ Number of fruits } & \multicolumn{2}{|c|}{$\begin{array}{l}\text { Fresh weight of } \\
\text { fruits /plant(g) }\end{array}$} & \multicolumn{2}{|c|}{$\begin{array}{l}\text { Dry weight of fruits } \\
\text { /plant(g) }\end{array}$} \\
\hline & & $\begin{array}{c}1^{\text {st }} \\
\text { Season }\end{array}$ & $\begin{array}{c}2^{\text {nd }} \\
\text { Season }\end{array}$ & $\begin{array}{c}1^{\text {st }} \\
\text { Season }\end{array}$ & $\begin{array}{c}2^{\text {nd }} \\
\text { Season }\end{array}$ & $\begin{array}{c}1^{\text {st }} \\
\text { Season }\end{array}$ & $\begin{array}{c}2^{\text {nd }} \\
\text { Season }\end{array}$ & $\begin{array}{c}1^{\text {st }} \\
\text { Season }\end{array}$ & $\begin{array}{c}2^{\text {nd }} \\
\text { Season }\end{array}$ & $\begin{array}{c}1^{\text {st }} \\
\text { Season }\end{array}$ & $\begin{array}{c}2^{\text {nd }} \\
\text { Season }\end{array}$ & $\begin{array}{c}1^{\text {st }} \\
\text { Season }\end{array}$ & $\begin{array}{l}2^{\text {nd }} \\
\text { Season }\end{array}$ \\
\hline \multirow{5}{*}{$\begin{array}{l}\text { Traditional } \\
\text { irrigation } \\
\text { (control) } I_{0}\end{array}$} & Control & 205.33 & 181.33 & 7.67 & 5.33 & 3.67 & 3.05 & 61.67 & 56.00 & 238.24 & 208.78 & 59.66 & 46.98 \\
\hline & $\mathrm{Fe}$ & 217.00 & 194.67 & 11.00 & 8.33 & 4.56 & 3.46 & 81.00 & 59.67 & 257.99 & 212.69 & 96.64 & 83.82 \\
\hline & Zn & 224.33 & 206.67 & 12.00 & 8.67 & 5.90 & 4.39 & 89.00 & 89.00 & 339.83 & 262.90 & 137.98 & 92.99 \\
\hline & Mn & 234.67 & 209.67 & 12.00 & 8.33 & 6.56 & 6.44 & 148.33 & 109.00 & 397.85 & 318.83 & 201.53 & 117.80 \\
\hline & $\mathrm{Fe}+\mathrm{Zn}+\mathrm{Mn}$ & 263.00 & 243.33 & 27.67 & 20.33 & 9.37 & 7.39 & 163.33 & 128.33 & 842.46 & 628.67 & 242.24 & 191.93 \\
\hline \multirow{5}{*}{$\begin{array}{l}\text { Skipping } \\
\text { irrigation } \\
\text { at } \\
\text { vegetativ } \\
\text { e growth } \\
\text { stage } I_{1}\end{array}$} & Control & 207.00 & 182.67 & 8.67 & 6.33 & 2.92 & 3.94 & 61.67 & 47.33 & 147.67 & 103.08 & 65.50 & 54.60 \\
\hline & $\mathrm{Fe}$ & 216.67 & 186.00 & 10.00 & 7.33 & 3.94 & 3.90 & 63.67 & 46.33 & 173.93 & 114.70 & 72.30 & 66.81 \\
\hline & Zn & 214.00 & 192.33 & 13.00 & 8.33 & 4.99 & 4.39 & 78.33 & 64.67 & 355.48 & 229.07 & 92.13 & 86.01 \\
\hline & $\mathbf{M n}$ & 210.00 & 191.33 & 11.67 & 9.00 & 6.06 & 4.54 & 88.00 & 73.33 & 381.68 & 274.78 & 110.21 & 90.33 \\
\hline & $\mathrm{Fe}+\mathrm{Zn}+\mathrm{Mn}$ & 222.33 & 197.33 & 21.00 & 14.67 & 7.35 & 7.67 & 128.33 & 105.00 & 639.66 & 527.89 & 231.97 & 190.92 \\
\hline \multirow{5}{*}{$\begin{array}{l}\text { Skipping } \\
\text { irrigation } \\
\text { at } \\
\text { flowering } \\
\text { growth } \\
\text { stage } \mathrm{I}_{2} \\
\end{array}$} & Control & 170.00 & 139.33 & 7.00 & 5.00 & 3.53 & 3.27 & 63.33 & 52.67 & 216.45 & 144.67 & 51.74 & 45.14 \\
\hline & $\mathrm{Fe}$ & 210.33 & 176.00 & 9.33 & 6.33 & 4.29 & 3.82 & 73.67 & 52.67 & 286.49 & 168.78 & 69.16 & 57.92 \\
\hline & $\mathrm{Zn}$ & 204.67 & 151.67 & 8.00 & 5.67 & 4.70 & 4.32 & 84.67 & 62.67 & 333.12 & 185.30 & 78.99 & 63.47 \\
\hline & Mn & 211.00 & 182.00 & 10.00 & 8.33 & 4.55 & 4.45 & 103.33 & 92.67 & 470.42 & 287.51 & 115.75 & 92.63 \\
\hline & $\mathrm{Fe}+\mathrm{Zn}+\mathrm{Mn}$ & 218.00 & 194.33 & 16.67 & 11.67 & 5.27 & 4.86 & 134.67 & 105.00 & 535.60 & 455.39 & 126.04 & 100.96 \\
\hline \multirow{6}{*}{$\begin{array}{c}\text { Skipping } \\
\text { irrigation } \\
\text { at fruits } \\
\text { formation } \\
\text { growth } \\
\text { stage } I_{3}\end{array}$} & Control & 202.00 & 183.67 & 9.33 & 6.33 & 2.41 & 3.34 & 66.00 & 52.67 & 156.44 & 140.14 & 67.77 & 56.43 \\
\hline & $\mathrm{Fe}$ & 211.67 & 185.33 & 11.67 & 7.33 & 4.09 & 4.09 & 64.67 & 55.67 & 192.90 & 183.04 & 92.80 & 85.72 \\
\hline & Zn & 211.33 & 182.00 & 11.00 & 7.33 & 5.86 & 5.03 & 89.67 & 75.00 & 223.37 & 230.61 & 111.29 & 92.83 \\
\hline & $\mathbf{M n}$ & 206.00 & 191.00 & 10.67 & 7.33 & 5.31 & 4.99 & 99.33 & 82.00 & 393.94 & 346.43 & 121.19 & 96.95 \\
\hline & $\mathrm{Fe}+\mathrm{Zn}+\mathrm{Mn}$ & 210.00 & 197.67 & 13.33 & 9.00 & 6.77 & 5.63 & 136.67 & 95.33 & 556.22 & 452.72 & 158.87 & 107.45 \\
\hline & LSD 0.05 & $18.17^{* \star *}$ & $14.19^{* * *}$ & $2.13^{* \star \star}$ & $1.92^{* \star \star}$ & $0.64^{\star \star \star}$ & $0.28^{\star \star *}$ & $14.61^{* * *}$ & $5.34^{\star \star *}$ & $22.82^{* \star *}$ & $65.49^{* \star}$ & $13.97^{* * *}$ & $7.08^{\star * \star}$ \\
\hline \multirow{5}{*}{$\begin{array}{l}\text { Irrigation } \\
\text { mean }\end{array}$} & $\mathrm{I}_{0}$ & 228.87 & 207.13 & 14.07 & 10.20 & 6.01 & 4.95 & 108.67 & 88.40 & 415.28 & 326.37 & 147.61 & 106.70 \\
\hline & $I_{1}$ & 214.00 & 189.93 & 12.87 & 9.13 & 5.05 & 4.89 & 84.00 & 67.33 & 339.68 & 249.90 & 114.43 & 97.73 \\
\hline & $\mathrm{I}_{2}$ & 202.80 & 168.67 & 10.20 & 7.40 & 4.47 & 4.14 & 91.93 & 73.13 & 368.41 & 248.33 & 88.34 & 72.02 \\
\hline & $I_{3}$ & 208.20 & 187.93 & 11.20 & 7.47 & 4.89 & 4.62 & 91.27 & 72.13 & 304.58 & 270.59 & 110.38 & 87.87 \\
\hline & LSD 0.05 & $8.13^{* *}$ & $6.35^{* * *}$ & $0.95^{\star *}$ & $0.86^{* *}$ & $0.29^{* *}$ & $0.12^{* * *}$ & $6.53^{*}$ & $2.39^{* * *}$ & $20.06^{* * *}$ & $29.29^{\star \star \star *}$ & $6.25^{\star \star *}$ & $3.17^{* * *}$ \\
\hline \multirow{6}{*}{$\begin{array}{c}\text { Foliar } \\
\text { applicatio } \\
\text { n mean }\end{array}$} & Control & 196.08 & 171.75 & 8.16 & 5.75 & 3.13 & 3.40 & 63.17 & 52.17 & 189.70 & 149.17 & 61.17 & 50.79 \\
\hline & $\mathrm{Fe}$ & 213.92 & 185.50 & 10.50 & 7.33 & 4.22 & 3.82 & 70.75 & 53.58 & 227.83 & 169.80 & 82.72 & 73.57 \\
\hline & $\mathrm{Zn}$ & 213.58 & 183.17 & 11.00 & 7.50 & 5.36 & 4.53 & 85.42 & 72.83 & 312.95 & 226.97 & 105.10 & 83.82 \\
\hline & $M n$ & 215.42 & 193.50 & 11.08 & 8.25 & 5.62 & 5.10 & 109.75 & 89.25 & 410.97 & 306.89 & 137.17 & 99.43 \\
\hline & $\mathrm{Fe}+\mathrm{Zn}+\mathrm{Mn}$ & 228.33 & 208.17 & 19.67 & 13.92 & 7.19 & 6.39 & 140.75 & 108.42 & 643.49 & 516.17 & 189.78 & 147.81 \\
\hline & LSD 0.05 & $5.65^{\star \star *}$ & $3.90^{* * *}$ & $1.39^{* * *}$ & $0.78^{\star * *}$ & $0.25^{\star * *}$ & $0.33^{\star * *}$ & $5.18^{\star * *}$ & $4.21^{\star * *}$ & $22.82^{\star \star *}$ & $20.18^{\star * *}$ & $5.33^{\star \star *}$ & $3.01^{\star * *}$ \\
\hline
\end{tabular}

\section{Effect of different treatments on production:}

It is clear from Table (2) that skipping one irrigation at any stage of growth significantly decreased all yield characters i.e. fresh weight of calyxes /plant, dry weight of calyxes /plant, calyxes yield/fed, fibers yield/fed, seeds yield/plant and seeds yield/fed in the two seasons. Higher reduction of all abovementioned characters was registered when roselle plants were exposed to skipping irrigation at flowering growth stage. Water stress at fruits formation came in the second order with respect to these features, while early stress at vegetative growth stage has less detrimental effect on these attributes except that of fresh weight of calyxes /plant which the higher reduction were obtained when plants exposed to skipping irrigation at fruits formation. Water stress at flowering came in the second order and early stress at vegetative has less detrimental effect compared with the traditional irrigation (control) which promoted production characters and resulted 
in higher fresh weight of calyxes /plant, dry weight of calyxes /plant, calyxes yield/fed, fibers yield/fed, seeds yield/plant and seeds yield/fed in the two seasons. These results are in agreement with those obtained by El- Boraie et al. (2009). The expected depression as a result of water stress on yield of roselle plants may be due to the reduction of growth criteria as indicated in Table (1) in addition, irrigation is critical during fruits filling and flowering stages in roselle plants mainly because of the higher leaf area index during these periods and consequently, the greater demand for water. .In this concern Mafakheri et al. (2010) stated that Plants grown under drought condition have a lower stomatal conductance in order to conserve water. Consequently, $\mathrm{CO}_{2}$ fixation is reduced and photosynthetic rate decreases, resulting in less assimilate production for growth and yield of plants.

Irrespective to water stress, foliar application of $\mathrm{Fe}, \mathrm{Zn}, \mathrm{Mn}$ and their combination significantly increased all the yield characters (fresh weight of calyxes /plant, dry weight of calyxes /plant, calyxes yield/fed, fibers yield/fed, seeds yield/plant and seeds yield/fed ) compared with the control plants in the two seasons. Fe+ $\mathrm{Zn}+\mathrm{Mn}$ foliar application had the greatest stimulatory effect on all yield attributes. The mean values of foliar application can be descended in order to combination, $\mathrm{Mn}>\mathrm{Zn}>\mathrm{Fe}>$ control. These results showed the significant increase in calyxes yield/fed, fibers yield/fed and seeds yield/fed from $552.06 \mathrm{~kg} / \mathrm{fed}, 3.13$ ton $/ \mathrm{fed}$ and $945.49 \mathrm{~kg} / \mathrm{fed}$ in control to $1486.57 \mathrm{~kg} / \mathrm{fed}, 7.19$ ton/fed and $3224.10 \mathrm{~kg} / \mathrm{fed}$ in the first season, respectively with application of $\mathrm{Fe}+\mathrm{Zn}+\mathrm{Mn}$ which estimated by 62.86 , 56.47 and $70.67 \%$ higher calyxes yield/fed, fibers yield/fed and seeds yield/fed, respectively over the control .The increase in yield characters by $\mathrm{Fe}+\mathrm{Zn}+\mathrm{Mn}$ foliar application might be related to its effect on water plant relationship as well as metabolic and physiological activities of roselle plant . Moreover, a sufficient zinc and iron nutrition also has protective effects on photo oxidative damage catalyzed by ROS in chloroplasts and other important organs during photosynthesis (Wang and Jin 2005). Such results confirmed the data reported by El-Fouly et al. (2011). Rehm and Albert (2006) reported that, yields were higher for the treatments with micronutrients. Concerning the effect of interaction, data presented in Table (2) indicated that the highest values of fresh weight of calyxes /plant, dry weight of calyxes/plant, calyxes yield/fed, fibers yield/fed, seeds yield/plant and seeds yield/fed were recorded by irrigating the plants Traditionally (control) and sprayed with $\mathrm{Fe}+\mathrm{Zn}+\mathrm{Mn}$ in the two seasons, While the highest reduction in all characters were recorded by skipping irrigation at flowering stage with distilled water spraying except that of fresh weight of calyxes /plant which reduced by skipping 
irrigation at vegetative growth stage with distilled water spraying in the two seasons. Similar results were obtained by Hussein et al. (2013) who observed a significantly higher yield of barley at amino (Amino acids $+\mathrm{Zn}(24 \%)+\mathrm{Mn}(2 \%)+\mathrm{Fe}(2 \%)+\mathrm{Mg}(1 \%)$ at the rate of liter/fed. $(\mathrm{Am})+$ potassium foliar application treatment under normal irrigation .Such increase in yield may be attributed to the foliar applied nutrients have limited direct use for enhancement of stress resistance mechanisms in field crops, Lavon, et al. (1999). Furthermore, Grewall and Williams (2000) found that adequate $\mathrm{Zn}$ nutrition enhanced alfalfa plants growth under the condition of water stress during early vegetative stage. $\mathrm{Zn}$ and $\mathrm{Fe}$ are involved in detoxification of reactive oxygen specious (ROS) and they are also important for reducing the production of free radicals by superoxide radical producing enzymes (Cakmak, 2000).

Effect of different treatments on chemical composition: Table (3) illustrated that with holding one irrigation at any growth stage led to increasing in total anthocyanin, T.S.S, acidity\%, pH and T.S.S acidity ratio in calyxes roselle plants as comparing with traditional irrigation (control) in the two seasons. It is worthy to note also that high total anthocyanin and $\mathrm{pH}$ in the two seasons and T.S.S in the first season and T.S.S acidity ratio in the second one in calyxes roselle plants subjected to water stress at fruits formation growth stage in the two seasons .Furthermore, early stress at vegetative growth stage has increased acidity\% in the two seasons and T.S.S in the second seasons .While, stress at flowering stage recorded the highest T.S.S. acidity ratio in the first season. The obtained results are in agreement with the findings of Nabizadeh et al , 2012. 
Table 2: Effect of skipping one irrigation and foliar application of some micronutrients on fresh weight of calyxes /plant, dry weight of calyxes /plant, calyxes yield/fed, weight of 1000 seeds, seeds yield/plant and seeds yield/fed of roselle plants in 2014-2015 seasons

\begin{tabular}{|c|c|c|c|c|c|c|c|c|c|c|c|c|c|}
\hline \multirow{2}{*}{$\begin{array}{l}\text { irrigation } \\
\text { Treatment } \\
\text { s }\end{array}$} & \multirow{2}{*}{$\begin{array}{c}\text { Foliar } \\
\text { application }\end{array}$} & \multicolumn{2}{|c|}{$\begin{array}{l}\text { Fresh weight of } \\
\text { calyxes /plant }(\mathrm{g})\end{array}$} & \multicolumn{2}{|c|}{$\begin{array}{c}\text { Dry weight of } \\
\text { calyxes /plant(g) }\end{array}$} & \multicolumn{2}{|c|}{$\begin{array}{c}\text { Calyxes } \\
\text { yield/fed }(\mathrm{kg})\end{array}$} & \multicolumn{2}{|c|}{$\begin{array}{l}\text { Weight of } \\
1000 \text { seeds }\end{array}$} & \multicolumn{2}{|c|}{$\begin{array}{c}\text { Seeds } \\
\text { yield/plant(g) }\end{array}$} & \multicolumn{2}{|c|}{ Seeds yield/fed(kg) } \\
\hline & & $\begin{array}{c}1^{\text {st }} \\
\text { Season }\end{array}$ & $\begin{array}{c}2^{\text {nd }} \\
\text { Season }\end{array}$ & $\begin{array}{c}1^{\text {st }} \\
\text { Season }\end{array}$ & $\begin{array}{c}1^{\text {st }} \\
\text { Season }\end{array}$ & $\begin{array}{c}2^{\text {nd }} \\
\text { Season }\end{array}$ & $\begin{array}{c}1^{\text {st }} \\
\text { Season }\end{array}$ & $\begin{array}{c}1^{\mathrm{st}} \\
\text { Season }\end{array}$ & $\begin{array}{c}2^{\text {nd }} \\
\text { Season }\end{array}$ & $\begin{array}{c}1^{\text {st }} \\
\text { Season }\end{array}$ & $\begin{array}{c}2^{\text {nd }} \\
\text { Season }\end{array}$ & $\begin{array}{c}1^{\text {st }} \\
\text { Season }\end{array}$ & $\begin{array}{c}2^{\text {nd }} \\
\text { Season }\end{array}$ \\
\hline \multirow{5}{*}{$\begin{array}{l}\text { Traditional } \\
\text { irrigation } \\
(\text { control }) I_{0}\end{array}$} & Control & 118.25 & 98.59 & 37.23 & 30.80 & 856.37 & 708.48 & 37.43 & 32.10 & 46.10 & 38.13 & 1060.30 & 877.07 \\
\hline & $\mathrm{Fe}$ & 124.79 & 106.4 & 48.23 & 34.69 & 1109.29 & 797.79 & 37.93 & 33.90 & 72.67 & 53.99 & 1671.33 & 1241.77 \\
\hline & $\mathrm{Zn}$ & 141.74 & 117.96 & 48.68 & 36.73 & 1119.72 & 844.71 & 39.13 & 35.37 & 90.76 & 66.69 & 2087.40 & 1533.95 \\
\hline & Mn & 305.87 & 205.67 & 61.55 & 51.87 & 1415.73 & 1193.09 & 39.63 & 36.40 & 137.36 & 99.53 & 3159.28 & 2289.27 \\
\hline & $\mathrm{Fe}+\mathrm{Zn}+\mathrm{Mn}$ & 455.95 & 366.35 & 95.47 & 84.32 & 2195.73 & 1939.44 & 42.70 & 38.33 & 176.05 & 140.81 & 4049.23 & 3238.55 \\
\hline \multirow{5}{*}{$\begin{array}{l}\text { Skipping } \\
\text { irrigation } \\
\text { at } \\
\text { vegetative } \\
\text { growth } \\
\text { stage } \mathrm{I}_{1}\end{array}$} & Control & 62.50 & 60.88 & 20.23 & 17.49 & 465.21 & 402.35 & 36.40 & 31.00 & 43.18 & 37.80 & 993.14 & 869.40 \\
\hline & & 91.75 & 74.66 & 33.97 & 21.85 & 781.31 & 502.55 & 37.10 & 31.60 & 50.97 & 38.33 & 39 & 881.67 \\
\hline & & 147.42 & 106.45 & 51.07 & 36.30 & 1174 & 834.82 & 38.70 & 32.60 & 63.71 & 46.77 & .41 & 1075.79 \\
\hline & Mn & 186.97 & 174.75 & 61.46 & 51.87 & 1413.50 & 1252.50 & 39.30 & 34.43 & 83.25 & 65.42 & 1914.83 & 1504.66 \\
\hline & $\mathrm{Fe}+\mathrm{Zn}+\mathrm{Mn}$ & & 206.84 & 73.38 & & & 1493.54 & & 35.13 & & & & \\
\hline \multirow{5}{*}{$\begin{array}{l}\text { Skipping } \\
\text { irrigation } \\
\text { at } \\
\text { flowering } \\
\text { growth } \\
\text { stage } I_{2}\end{array}$} & & 5.33 & 74.39 & 16.85 & 13.59 & 387.55 & 312.49 & 32.97 & 29.97 & 34.00 & 27.82 & 782.00 & 639.86 \\
\hline & & 123.67 & 105.01 & 18.93 & 15.49 & 435.39 & 356.27 & 34.07 & 31.23 & 38.57 & 30.41 & 887.03 & 649.43 \\
\hline & & 142.43 & 115.80 & 21.09 & 18.73 & 485.15 & 430.71 & 36.83 & 32.47 & 50.74 & 42.05 & 1167.02 & 967.23 \\
\hline & Mn & 201.33 & 190.90 & 38.33 & 33.95 & 881.67 & 780.93 & 37.38 & 32.63 & 84.43 & 63.77 & 1941.81 & 1466.79 \\
\hline & $\mathrm{Fe}+\mathrm{Zn}+\mathrm{Mn}$ & 239.31 & 195.21 & 41.28 & 38.15 & 949.44 & 877.37 & 38.80 & 33.60 & 99.13 & 95.40 & 2279.91 & 2194.28 \\
\hline \multirow{6}{*}{ 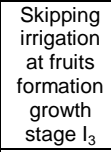 } & Control & 2.60 & 66.29 & 1.70 & 20.17 & 499.1 & 463.91 & 2.43 & 28.60 & 41.15 & 31.22 & 946.53 & 718.14 \\
\hline & . & 90.86 & 75.86 & 29.29 & 27.77 & 673.59 & 638.63 & 39.20 & 32.07 & 68.01 & 57.97 & 1564.23 & 1333.23 \\
\hline & Zn & 16.33 & 106.99 & 31.52 & 29.35 & 724.88 & 674.97 & 40.33 & 33.10 & 78.56 & 61.96 & 1806.88 & 1425.08 \\
\hline & & 149.96 & 122.75 & 38.13 & 28.85 & 876.91 & 663.47 & 41.67 & 35.00 & 95.43 & 72.84 & 2194.97 & 1675.32 \\
\hline & $\mathrm{Fe}+\mathrm{Zn}+\mathrm{Mn}$ & 253.27 & 205.67 & 48.40 & 43.78 & 1113.2 & 1006.94 & 42.80 & 38.50 & 119.03 & 104.89 & 2737.61 & 2412.47 \\
\hline & LSD .05 & $65.27^{\text {***}}$ & $10.26^{* \star \star}$ & $5.37^{* \star \star}$ & $4.41^{* \star *}$ & $131.73^{\star \star \star}$ & $101.43^{* * *}$ & $1.43^{* \star \star}$ & $1.48^{\star \star *}$ & $11.93^{\star \star \star}$ & $6.00^{* \star \star}$ & $274.33^{* \star \star}$ & $138.02^{* * *}$ \\
\hline \multirow{5}{*}{$\begin{array}{l}\text { Irrigation } \\
\text { mean }\end{array}$} & $\mathrm{I}_{0}$ & 229.32 & 178.99 & 58.23 & 47.68 & 1339.37 & 1096.70 & 39.37 & 35.22 & 104.59 & 79.83 & 2405.51 & 1836.12 \\
\hline & $I_{1}$ & 0.41 & 136.27 & 48.02 & 39.01 & 1104.52 & 897.15 & 38.47 & 32.95 & 81.52 & 64.52 & 1875.08 & 1483.90 \\
\hline & & 149.11 & 124.72 & 27.30 & 23.98 & 627.84 & 551.56 & 36.01 & 31.98 & 61.37 & 51.89 & 1411.56 & 1193.52 \\
\hline & & 3.60 & 5.51 & 33.81 & 29.98 & 777.54 & 689.59 & 39.29 & 33.45 & 80.44 & 65.78 & 1850.04 & 1512.85 \\
\hline & & $29.19^{* *}$ & $4.59^{* * *}$ & $2.56^{* * *}$ & $1.79^{* \star *}$ & $58.91^{* * *}$ & $45.36^{\star * *}$ & $0.64^{* *}$ & $0.66^{*}$ & $5.33^{\star \star \star}$ & $2.68^{\star \star *}$ & $122.68^{* * *}$ & $61.72^{* * *}$ \\
\hline \multirow{6}{*}{$\begin{array}{l}\text { Foliar } \\
\text { applicatio } \\
\mathrm{n} \text { mean }\end{array}$} & Control & 89.67 & 75.04 & 24.00 & 20.51 & 552.06 & 471.81 & 34.81 & 30.42 & 41.11 & 33.74 & 945.49 & 776.12 \\
\hline & & 107.77 & 90.48 & 32.60 & 24.95 & 749.90 & 573.81 & 37.08 & 32.20 & 57.55 & 45.18 & 1323.75 & 1039.03 \\
\hline & $\mathrm{Zn}$ & 136.98 & 111.8 & 38.09 & 30.27 & 876.11 & 696.31 & 38.75 & 33.38 & 70.94 & 54.37 & 1631.68 & 1250.51 \\
\hline & & 211.03 & 173.52 & 49.87 & 42.24 & 1146.95 & 972.50 & 39.50 & 34.62 & 100.12 & 75.39 & 2302.72 & 1734.01 \\
\hline & $\mathrm{Fe}+\mathrm{Zn}+\mathrm{Mn}$ & 301.44 & 243.52 & 64.63 & 57.80 & 1486.57 & 1329.32 & 41.28 & 36.39 & 140.18 & 118.84 & 3224.10 & 2733.32 \\
\hline & LSD0.05 & $17.74^{\star \star *}$ & $4.74^{\star \star \star}$ & $2.52^{\star \star \star}$ & $1.58^{* * *}$ & $57.89^{\star \star *}$ & $35.50^{\star \star \star}$ & $0.49^{* *}$ & $0.46^{* * *}$ & $4.19^{\star \star \star}$ & $2.20^{\star * *}$ & $96.34^{\star * *}$ & $50.60^{* * *}$ \\
\hline
\end{tabular}

It is clear from Table (3) that there was significant increase in chemical composition of roselle due to foliar application as comparing with the control .However, spraying plants with $\mathrm{Zn}$ recorded the highest total anthocyanin, acidity, $\mathrm{pH}$ and T.S.S in the two seasons. While, distilled water spraying in the first season and Mn spraying in the second one recorded the highest T.S.S. acidity ratio. The positive effects of $\mathrm{Zn}$ on plant may be due to their effects as a metal component of some enzymes or regulatory for the others. Moreover, they have essential roles in plant metabolism (Abd El-Hady 2007). These results are in full agreement with those obtained by Nasiri et al. (2010) and Akbari et al. (2013). Furthermore, Abdalla et al., 1992 pointed out that in addition micronutrients spraying led to increasing macro and micronutrients uptake as a result of improving root growth which consequently led to great absorbing surface. 
Table 3: Effect of skipping one irrigation and foliar application of some micronutrients on total anthocyanin, T.S.S, acidity, pH and T.S.S acidity ratio of roselle plants in 2014-2015 seasons

\begin{tabular}{|c|c|c|c|c|c|c|c|c|c|c|c|}
\hline \multirow{2}{*}{$\begin{array}{l}\text { irrigation } \\
\text { Treatments }\end{array}$} & \multirow{2}{*}{$\begin{array}{l}\text { Foliar } \\
\text { application }\end{array}$} & \multicolumn{2}{|c|}{$\begin{array}{c}\text { Total anthocyanin } \\
(\mathrm{mg} / 100 \mathrm{~g})\end{array}$} & \multicolumn{2}{|c|}{ T.S.S (Brix) } & \multicolumn{2}{|c|}{ Acidity\% } & \multicolumn{2}{|c|}{$\mathrm{pH}$} & \multicolumn{2}{|c|}{ T.S.S Acidity ratio } \\
\hline & & $\begin{array}{c}1^{\text {st }} \\
\text { Season }\end{array}$ & $\begin{array}{c}2^{\text {nd }} \\
\text { Season }\end{array}$ & $\begin{array}{c}1^{\text {st }} \\
\text { Season }\end{array}$ & $\begin{array}{c}2^{\text {nd }} \\
\text { Season }\end{array}$ & $\begin{array}{c}1^{\text {st }} \\
\text { Season }\end{array}$ & $\begin{array}{c}2^{\text {nd }} \\
\text { Season }\end{array}$ & $1^{\text {st }}$ Season & $\begin{array}{c}2^{\text {nd }} \\
\text { Season }\end{array}$ & $1^{\text {st }}$ Season & $2^{\text {nd }}$ Season \\
\hline \multirow{5}{*}{$\begin{array}{l}\text { Traditional } \\
\text { irrigation } \\
(\text { control }) I_{0}\end{array}$} & Control & 265.35 & $262 . .49$ & 5.90 & 4.97 & 3.24 & 2.82 & 3.06 & 2.96 & 1.82 & 1.76 \\
\hline & $\mathrm{Fe}$ & 269.52 & 263.68 & 6.03 & 5.27 & 3.75 & 3.05 & 3.26 & 3.01 & 1.62 & 1.73 \\
\hline & $\mathrm{Zn}$ & 316.64 & 310.08 & 6.33 & 6.00 & 4.01 & 3.56 & 3.27 & 3.10 & 1.58 & 1.69 \\
\hline & $\mathrm{Mn}$ & 314.73 & 281.57 & 6.10 & 5.57 & 3.50 & 3.00 & 3.23 & 2.98 & 1.74 & 1.86 \\
\hline & $\mathrm{Fe}+\mathrm{Zn}+\mathrm{Mn}$ & 311.51 & 264.64 & 6.23 & 5.73 & 3.75 & 3.15 & 3.25 & 3.02 & 1.66 & 1.83 \\
\hline \multirow{5}{*}{$\begin{array}{c}\text { Skipping } \\
\text { irrigation at } \\
\text { vegetative } \\
\text { growth stage } \mathrm{I}_{1}\end{array}$} & Control & 262.97 & 262.73 & 5.20 & 4.80 & 2.90 & 2.65 & 3.09 & 2.82 & 1.79 & 1.82 \\
\hline & $\mathrm{Fe}$ & 264.40 & 263.69 & 6.13 & 5.77 & 4.01 & 3.16 & 3.16 & 3.12 & 1.53 & 1.83 \\
\hline & $\mathrm{Zn}$ & 270.72 & 271.91 & 7.10 & 6.40 & 4.52 & 3.56 & 3.44 & 3.21 & 1.57 & 1.80 \\
\hline & $\mathrm{Mn}$ & 268.33 & 271.91 & 6.27 & 5.60 & 3.50 & 3.23 & 3.25 & 2.92 & 1.79 & 1.73 \\
\hline & $\mathrm{Fe}+\mathrm{Zn}+\mathrm{Mn}$ & 265.95 & 267.14 & 6.40 & 6.00 & 4.01 & 3.73 & 3.31 & 3.10 & 1.60 & 1.61 \\
\hline \multirow{5}{*}{$\begin{array}{c}\text { Skipping } \\
\text { irrigation at } \\
\text { flowering } \\
\text { growth stage } I_{2}\end{array}$} & Control & 267.98 & 261.18 & 5.30 & 4.50 & 2.90 & 2.20 & 3.16 & 3.02 & 1.83 & 2.05 \\
\hline & $\mathrm{Fe}$ & 273.10 & 262.61 & 6.50 & 5.60 & 3.41 & 3.07 & 3.20 & 3.06 & 1.91 & 1.83 \\
\hline & $\mathrm{Zn}$ & 314.01 & 305.66 & 6.90 & 6.00 & 3.75 & 3.17 & 3.42 & 3.21 & 1.84 & 1.89 \\
\hline & Mn & 311.39 & 305.07 & 5.60 & 5.00 & 3.24 & 2.82 & 3.25 & 3.10 & 1.73 & 1.77 \\
\hline & $\mathrm{Fe}+\mathrm{Zn}+\mathrm{Mn}$ & 307.69 & 263.45 & 6.53 & 5.67 & 3.50 & 3.00 & 3.29 & 3.15 & 1.87 & 1.89 \\
\hline \multirow{6}{*}{$\begin{array}{c}\text { Skipping } \\
\text { irrigation at } \\
\text { fruits formation } \\
\text { growth stage } I_{3}\end{array}$} & Control & 273.10 & 262.97 & 6.00 & 5.00 & 2.99 & 2.22 & 3.27 & 3.07 & 2.01 & 2.26 \\
\hline & $\mathrm{Fe}$ & 276.68 & 264.28 & 6.50 & 5.40 & 3.50 & 2.99 & 3.28 & 3.18 & 1.83 & 1.81 \\
\hline & $\mathrm{Zn}$ & 314.61 & 310.08 & 6.90 & 6.27 & 4.52 & 3.73 & 3.52 & 3.24 & 1.73 & 1.68 \\
\hline & Mn & 313.65 & 307.69 & 5.60 & 5.73 & 3.50 & 2.99 & 3.28 & 3.15 & 1.75 & 1.92 \\
\hline & $\mathrm{Fe}+\mathrm{Zn}+\mathrm{Mn}$ & 312.58 & 267.14 & 6.53 & 5.80 & 4.01 & 3.13 & 3.33 & 3.08 & 1.67 & 1.85 \\
\hline & LSD 0.05 & $3.24^{\star \star *}$ & $2.90^{* \star \star}$ & $0.13^{* \star \star}$ & $0.19^{\star \star \star}$ & $0.41^{\star \star \star}$ & $0.16^{\star \star \star}$ & $0.04^{\star \star \star}$ & $0.03^{\star \star \star}$ & $0.18^{* \star \star}$ & $0.12^{\star \star \star}$ \\
\hline \multirow{5}{*}{ Irrigation mean } & $I_{0}$ & 295.55 & 276.49 & 6.12 & 5.51 & 3.65 & 3.12 & 3.21 & 3.01 & 1.68 & 1.77 \\
\hline & $I_{1}$ & 266.47 & 267.47 & 6.22 & 5.71 & 3.79 & 3.27 & 3.25 & 3.03 & 1.66 & 1.76 \\
\hline & $\mathrm{I}_{2}$ & 294.83 & 279.59 & 6.17 & 5.36 & 3.36 & 2.85 & 3.26 & 3.11 & 1.83 & 1.89 \\
\hline & $I_{3}$ & 298.13 & 282.43 & 6.61 & 5.64 & 3.70 & 3.01 & 3.37 & 3.14 & 1.80 & 1.90 \\
\hline & LSD0.05 & $1.45^{\star \star \star}$ & $1.30^{\star \star *}$ & $0.06^{* \star *}$ & $0.09^{\star \star \star}$ & $0.18^{\text {** }}$ & $0.07^{* \star \star}$ & $0.02^{* *}$ & $0.02^{\star \star \star}$ & $0.08^{* *}$ & $0.05^{\star \star \star}$ \\
\hline \multirow{6}{*}{$\begin{array}{l}\text { Foliar } \\
\text { application } \\
\text { mean }\end{array}$} & Control & 267.35 & 262.34 & 5.6 & 4.82 & 3.01 & 2.47 & 3.14 & 2.97 & 1.86 & 1.79 \\
\hline & $\mathrm{Fe}$ & 270.93 & 263.57 & 6.27 & 5.52 & 3.67 & 3.07 & 3.22 & 3.09 & 1.76 & 1.80 \\
\hline & $\mathrm{Zn}$ & 303.99 & 299.43 & 7.03 & 6.17 & 4.20 & 3.51 & 3.41 & 3.19 & 1.68 & 1.77 \\
\hline & Mn & 302.03 & 291.56 & 6.03 & 5.48 & 3.43 & 3.01 & 3.26 & 3.04 & 1.76 & 1.82 \\
\hline & $\mathrm{Fe}+\mathrm{Zn}+\mathrm{Mn}$ & 299.43 & 265.59 & 6.47 & 5.80 & 3.82 & 3.25 & 3.30 & 3.09 & 1.70 & 1.79 \\
\hline & LSD0.05 & $1.15^{\star \star \star}$ & $0.96^{* \star *}$ & $0.06^{* * *}$ & $0.07^{* * *}$ & $0.11^{* * *}$ & $0.09^{* * *}$ & $0.01^{* \star *}$ & $0.01^{* * *}$ & $0.05^{* \star *}$ & $0.07^{* * *}$ \\
\hline
\end{tabular}

The interaction between water stress and foliar application had a significant effect on all chemical composition. The highest values of total anthocyanin, acidity, PH and T.S.S were recorded by skipping irrigation at fruits formation growth stage with $\mathrm{Zn}$ spraying in two seasons. While, the highest values of T.S.S acidity ratio were recorded by Skipping irrigation at fruits formation growth stage without spraying (control) in the two seasons. Such enhancement effect of Zn spraying on roselle plants grown under water stress conditions counteracted the deleterious effects of stress on chemical composition, especially the stress at fruits formation growth and helped stressed plants to grow successfully under these adverse unfavorable conditions. These results were in harmony with those obtained by Thalooth et al. (2006) and Zaki et al. (2013) Moreover, Said-Al Ahl and Mahmoud (2010) reported that basil plants sprayed with zinc and /or iron under normal and saline conditions were superior compared with non-sprayed plants. 


\section{Water relations:}

\section{Amount of Seasonal irrigation water applied (Wa, $\left.\mathrm{cm} \& \mathrm{~m}^{3} / \mathrm{fed}\right)$.}

Presented data in Table (4) clearly showed that the highest values for $(\mathrm{Wa})$ were recorded under traditional irrigation and the values are $91.98 \mathrm{~cm}$ (3863.33 m/3 $/ \mathrm{fed}$.) and $88.31 \mathrm{~cm}(3709.13$ $\mathrm{m}^{3} / \mathrm{fed}$.). Meanwhile, the lowest values for (Wa) were recorded under skipping irrigation at vegetative growth stage $l_{1}$ and the values are $83.80 \mathrm{~cm}\left(3519.69 \mathrm{~m}^{3} / \mathrm{fed}\right.$.) and $81.17 \mathrm{~cm}\left(3409.08 \mathrm{~m}^{3} / \mathrm{fed}\right.$.) in the first and second growing seasons, respectively.

Table (4): Effect of irrigation treatments and some micronutrients foliar application on seasonal amount of water applied $\left(\mathrm{cm}\right.$ and $\left.\mathrm{m}^{3} / \mathrm{fed}\right)$ and percentage of saving water (\%) for roselle plants in the two seasons

\begin{tabular}{|c|c|c|c|c|c|c|c|c|c|}
\hline \multirow{2}{*}{\begin{tabular}{|} 
Irrigation \\
treatments
\end{tabular}} & \multicolumn{4}{|c|}{$1^{\text {st }}$ season } & \multicolumn{3}{c|}{$2^{\text {nd }}$ season } & \multicolumn{3}{|c|}{$\begin{array}{c}\text { The overall mean values through } \\
\text { the two seasons }\end{array}$} \\
\cline { 2 - 11 } & $\begin{array}{c}\text { Water } \\
\text { applied } \\
\mathrm{cm}\end{array}$ & $\begin{array}{c}\text { Water } \\
\text { applied } \\
\left(\mathrm{m}^{3} / \mathrm{fed}\right)\end{array}$ & $\begin{array}{c}\text { Percentage } \\
\text { of saving } \\
\text { water }(\%)\end{array}$ & $\begin{array}{c}\text { Water } \\
\text { applied } \\
\mathrm{cm}\end{array}$ & $\begin{array}{c}\text { Water } \\
\text { applied } \\
\left(\mathrm{m}^{3} / \mathrm{fed}\right)\end{array}$ & $\begin{array}{c}\text { Percentage } \\
\text { of saving } \\
\text { water }(\%)\end{array}$ & $\begin{array}{c}\text { Water } \\
\text { applied } \\
\mathrm{cm}\end{array}$ & $\begin{array}{c}\text { Water } \\
\text { applied } \\
\left(\mathrm{m}^{3} / \mathrm{fed}\right)\end{array}$ & $\begin{array}{c}\text { Percentage } \\
\text { of saving } \\
\text { water }(\%)\end{array}$ \\
\hline $\mathrm{I}_{0}$ & 91.98 & 3863.33 & - & 88.31 & 3709.13 & - & 90.15 & 3786.23 & - \\
\hline$I_{1}$ & 83.80 & 3519.69 & 8.89 & 81.17 & 3409.08 & 8.09 & 82.49 & 3464.39 & 8.50 \\
\hline$I_{2}$ & 84.60 & 3553.13 & 8.03 & 81.66 & 3429.68 & 7.53 & 83.13 & 3491.41 & 7.79 \\
\hline$I_{3}$ & 87.02 & 3654.69 & 5.40 & 83.33 & 3499.65 & 5.65 & 85.17 & 3577.17 & 5.52 \\
\hline
\end{tabular}

Generally, the values of seasonal water applied can be descended in order $I_{0}>I_{3}>I_{2}>I_{1}$ in the two growing seasons. Increasing the values of seasonal amount of water applied under traditional irrigation $I_{0}$ in the two growing seasons in comparison with other irrigation treatments $I_{1}$, $\mathrm{I}_{2}$ and $\mathrm{I}_{3}$ might be attributed to increasing number of irrigations under irrigation treatment $I_{0}$ because it did not expose to water stress through the growing season. These results are in a great harmony with those obtained by Sidky et al. (2007), Mazrou et al. (2002), Meowad et al. (2005), Thalooth et al. (2006), Younis et al. (2009) Rashed and Moursi (2012), Hussein et al. (2013), Soha and Yousef (2014) and Moursi et al. (2014).

\section{2-Water consumptive use. $\mathrm{Cu}$ ( $\mathrm{cm} \& \mathrm{~m}^{3} /$ fed.):}

Tabulated data in Table (5) illustrated that the values of water consumptive use $(\mathrm{Cu})$ were greatly affected by both irrigation treatments and micronutrients foliar application in the two growing seasons. Regarding, the effect of irrigation treatments, the highest seasonal values of water consumptive use were recorded under traditional irrigation $\mathrm{I}_{0}$ and the values are $64.79 \mathrm{~cm}, 2721.03 \mathrm{~m}^{3} / \mathrm{fed}$ 
and $63.42 \mathrm{~cm}, 2663.75 \mathrm{~m}^{3} / \mathrm{fed}$ in the two seasons, respectively. On the other hand, the lowest values were recorded under skipping irrigation at vegetative growth stage $I_{1}$ which consumed $59.78 \mathrm{~cm}$, $2510.96 \mathrm{~m} 3 /$ fed and $59.19 \mathrm{~cm}, 2485.81 \mathrm{~m}^{3} /$ fed in the first and second seasons, respectively. Generally, the values of water consumptive use can be descended in order $I_{0}>I_{3}>I_{2}>I_{1}$ in the two growing seasons. Increasing the values of $\mathrm{Cu}$ under irrigation treatment $\mathrm{I}_{0}$ in comparison with other treatments $I_{1}, I_{2}$ and $l_{3}$ which exposed to water stress during the growing season may be due to increasing amount of seasonal water applied under the conditions of traditional irrigation $\mathrm{I}_{0}$. Also, under increasing irrigation water applied, the plants become healthy with a thick vegetative cover. So, the exposed area to the sunlight increases. Consequently, increasing the rate of evaporation which considers one of the components of $\mathrm{Cu}$. Therefore, increasing the values of $\mathrm{Cu}$. These results are in a great harmony with those obtained by Sidky et al. (2007), Younis et al. (2009), Hussein et al. (2013) Soha and Yousef (2014) and Moursi et al. (2014) .

Concerning, the effect of micronutrients foliar application on the values of water consumptive use. Data in the same Table showed that under all irrigation treatments, the highest values for water consumptive use were recorded under foliar application of $(\mathrm{Fe}+\mathrm{Zn}+$ $\mathrm{Mn}$ ) comparing with application every nutrient as alone or without application (control) and the highest overall mean value is $65.15 \mathrm{~cm}$ $\left(2736.46 \mathrm{~m}^{3} / \mathrm{fed}\right.$.) under irrigation treatment $I_{0}$. Generally, the overall mean values can be descended in order $I_{0}>I_{3}>I_{2}>I_{1}$ and the values are

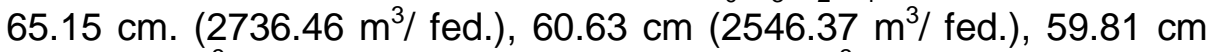
$\left(2511.99 \mathrm{~m}^{3} / \mathrm{fed}.\right)$ and $59.47 \mathrm{~cm}\left(2498.39 \mathrm{~m}^{3} / \mathrm{fed}\right.$.), respectively. Increasing the values of water consumptive use under foliar application treatment $(\mathrm{Fe}+\mathrm{Zn}+\mathrm{Mn})$ could be attributed to increasing vegetative cover and hence, increasing evaporation rate. So, increasing the values of $\mathrm{Cu}$. These results are in a great harmony with those reported by Thalooth et al. (2006), Hussein et al. (2013) and Moursi et al. (2014).

\section{3-Consumptive use efficiency (Ecu \%):}

Consumptive use efficiency (Ecu) is a parameter which indicates the capability of plants to utilize the soil moisture stored in the effective root zone .Presented data in Table (5) showed that the overall mean values of consumptive use efficiency (Ecu \%) through the two growing seasons were affected by both irrigation treatments and micronutrients foliar application. Concerning, the effect of irrigation treatments on (Ecu \%), the highest overall mean value was recorded under irrigation treatment $I_{1}$ and the value is $72.13 \%$. Meanwhile, the lowest overall mean value was recorded under irrigation treatment $I_{0}$ 
(traditional irrigation) and the value is $71.13 \%$. Generally, the overall mean values for Ecu can be descended in order $I_{1}>I_{2}>I_{3}>I_{0}$ and the overall mean values are $72.13,71.97,71.20$ and $71.13 \%$, respectively. Data in the same Table declared that the mean values of Ecu were higher under water stress conditions $I_{1}, I_{2}$ and $I_{3}$ in comparison with non-stress one $\mathrm{I}_{0}$. Increasing the values of Ecu under water stress conditions might be attributed to decreasing the amounts of water applied, higher amounts of irrigation water could be beneficially used by the growing plants which results in minimizing water losses. These results are in the same line with those reported by Kassab and Ibrahim (2007), Younis et al. (2009) and Moursi et al. (2014.)

Regarding, the effect of micronutrients foliar application on consumptive use efficiency. Data in the same Table indicated that the overall mean values for Ecu were increased under micronutrients foliar application in comparison with non-application (control treatment). The highest overall mean value was recorded under foliar application treatment $(\mathrm{Fe}+\mathrm{Zn}+\mathrm{Mn})$ comparing with application every nutrient as alone and without application (control). These results are in the same line with those obtained by Moursi et al. (2014)

Table (5): Effect of irrigation treatments and some micronutrients foliar application on seasonal amount of water consumptive use $(\mathrm{cm}$ and $\mathrm{m}^{3} / \mathrm{fed}$ ) and consumptive use efficiency $\%$ for roselle plants in the two seasons

\begin{tabular}{|c|c|c|c|c|c|c|c|c|c|c|}
\hline \multirow{2}{*}{ 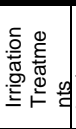 } & \multirow{2}{*}{$\begin{array}{l}\text { Micro } \\
\text { nutrients } \\
\text { foliar } \\
\text { application }\end{array}$} & \multicolumn{3}{|c|}{$1^{\text {st }}$ season } & \multicolumn{3}{|c|}{$2^{\text {nd }}$ season } & \multicolumn{3}{|c|}{$\begin{array}{l}\text { The overall mean values through the } \\
\text { two seasons }\end{array}$} \\
\hline & & \begin{tabular}{|c|} 
Water \\
consumptive \\
use, $\mathrm{cm}$ \\
\end{tabular} & \begin{tabular}{|c|} 
Water \\
consumptive \\
use $\left(\mathrm{m}^{3} / \mathrm{fed}\right)$ \\
\end{tabular} & $\begin{array}{c}\text { Consumptiv } \\
\text { e use } \\
\text { efficiency \% }\end{array}$ & $\begin{array}{c}\text { Water } \\
\text { consumptive } \\
\text { use } \mathrm{cm} \text {. }\end{array}$ & \begin{tabular}{|c|} 
Water \\
consumptive \\
use (m3/fed) \\
\end{tabular} & \begin{tabular}{|c}
$\begin{array}{c}\text { Consumptive } \\
\text { use efficiency } \\
\%\end{array}$ \\
\end{tabular} & \begin{tabular}{|c|} 
Water \\
consumptive \\
use, $\mathrm{cm} /$.
\end{tabular} & \begin{tabular}{|c|} 
Water \\
consumptive \\
use (m3/fed)
\end{tabular} & $\begin{array}{c}\text { Consumptiv } \\
\text { e use } \\
\text { efficiency \% }\end{array}$ \\
\hline \multirow{5}{*}{$\mathrm{I}_{0}$} & \multirow{5}{*}{$\begin{array}{c}\text { Control } \\
\mathrm{Fe} \\
\mathrm{Zn} \\
\mathrm{Mn} \\
\mathrm{Fe}+\mathrm{Zn}+\mathrm{Mn}\end{array}$} & \begin{tabular}{|l|}
63.73 \\
\end{tabular} & \begin{tabular}{|l|}
2676.63 \\
\end{tabular} & 69.28 & 62.53 & \begin{tabular}{|l|}
2626.28 \\
\end{tabular} & 70.81 & 63.13 & 2651.46 & 70.05 \\
\hline & & 64.17 & 2695.26 & 69.77 & 63.11 & 2650.77 & 71.47 & 63.64 & 2673.02 & 70.62 \\
\hline & & 64.55 & 2710.90 & 70.17 & 63.35 & 2660.84 & 71.74 & 63.95 & 2685.87 & 70.96 \\
\hline & & 65.48 & 2750.13 & 71.19 & 63.81 & 2680.18 & 72.26 & 64.65 & 2715.16 & 71.73 \\
\hline & & 66.01 & 2772.22 & 71.76 & 64.30 & 2700.70 & 72.81 & 65.15 & 2736.46 & 72.29 \\
\hline \multicolumn{2}{|r|}{ Mean } & 64.79 & 2721.03 & 70.43 & 63.42 & 2663.75 & 71.82 & 64.10 & 2692.39 & 71.13 \\
\hline \multirow[t]{5}{*}{$I_{1}$} & \multirow{5}{*}{$\begin{array}{c}\text { Control } \\
\mathrm{Fe} \\
\mathrm{Zn} \\
\mathrm{Mn} \\
\mathrm{Fe}+\mathrm{Zn}+\mathrm{Mn}\end{array}$} & 58.03 & 2437.27 & 69.25 & 57.40 & 2410.88 & 70.72 & 57.72 & 2424.08 & 69.99 \\
\hline & & 58.98 & 2477.33 & 70.38 & 58.58 & 2460.17 & 72.17 & 58.78 & 2468.75 & 71.28 \\
\hline & & 59.78 & 2510.78 & 71.34 & 58.46 & 2497.23 & 73.25 & 59.62 & 2504.01 & 72.30 \\
\hline & & 60.69 & 2549.17 & 72.43 & 59.77 & 2510.48 & 73.64 & 60.23 & 2559.83 & 73.04 \\
\hline & & 61.43 & 2580.24 & 73.31 & 60.72 & 2550.27 & 74.81 & 61.01 & 2565.26 & 74.06 \\
\hline \multicolumn{2}{|r|}{ Mean } & 59.78 & 2510.96 & 71.34 & 59.19 & 2485.81 & 72.92 & 59.47 & 2498.39 & 72.13 \\
\hline \multirow[t]{5}{*}{$I_{2}$} & \multirow{5}{*}{\begin{tabular}{|c|} 
Control \\
$\mathrm{Fe}$ \\
$\mathrm{Zn}$ \\
$\mathrm{Mn}$ \\
$\mathrm{Fe}+\mathrm{Zn}+\mathrm{Mn}$ \\
\end{tabular}} & 58.58 & 2460.43 & 69.25 & 57.39 & 2410.30 & 70.28 & 57.99 & 2435.37 & 69.77 \\
\hline & & 59.30 & 2490.72 & 70.10 & 58.22 & 2445.37 & 71.30 & 58.76 & 2468.05 & 70.70 \\
\hline & & 60.01 & 2520.47 & 70.94 & 59.30 & 2490.39 & 72.61 & 59.65 & 2505.43 & 71.78 \\
\hline & & 60.96 & 2560.18 & 72.05 & 59.78 & 2510.87 & 73.21 & 60.37 & 2535.53 & 72.63 \\
\hline & & 61.67 & 2590.31 & 72.90 & 62.88 & 2640.78 & 77.00 & 62.28 & 2615.55 & 74.95 \\
\hline \multicolumn{2}{|r|}{ Mean } & 60.10 & 2524.42 & 71.05 & 59.51 & 2499.54 & 72.88 & 56.81 & 2511.99 & 71.97 \\
\hline \multirow[t]{6}{*}{$I_{3}$} & \multirow{5}{*}{\begin{tabular}{|c|} 
Control \\
$\mathrm{Fe}$ \\
$\mathrm{Zn}$ \\
$\mathrm{Mn}$ \\
$\mathrm{Fe}+\mathrm{Zn}+\mathrm{Mn}$ \\
\end{tabular}} & 59.78 & 2510.77 & 68.70 & 58.59 & 2460.60 & 70.31 & 59.19 & 2485.69 & 69.51 \\
\hline & & 61.20 & 2570.33 & 70.33 & 59.12 & 2483.20 & 70.96 & 60.16 & 2526.77 & 70.65 \\
\hline & & 61.67 & 2590.23 & 70.87 & 59.48 & 2498.17 & 71.38 & 60.58 & 2544.20 & 71.13 \\
\hline & & 62.15 & 2610.50 & 71.43 & 59.77 & 2510.27 & 71.73 & 60.96 & 2560.39 & 71.58 \\
\hline & & 63.34 & 2660.48 & 72.80 & 61.17 & 2569.12 & 73.41 & 62.26 & 2614.80 & 73.11 \\
\hline & Mean & 61.63 & 2588.46 & 70.83 & 59.63 & 2504.27 & 71.56 & 60.63 & 2546.37 & 71.20 \\
\hline
\end{tabular}




\section{4-Water productivity (WP, $\mathrm{kg} / \mathrm{m}^{3}$ ) and productivity of irrigation water (PIW, $\mathbf{k g} / \mathbf{~ m}^{3}$ ) \\ Both (WP) and (PIW) are parameters which indicate the} productivity of water unit. This function could be evaluated in the two terms of water productivity which relates yield to water consumed. Productivity of irrigation water which relates to yield with the water applied. Presented data in Tables ( 6 and7) which showed the values of WP and PIW for different plant organs (fiber, calyxes, seeds/ fed and also for whole plant), both the studied treatments (irrigation and micronutrients foliar application), showed a great effect on the overall mean values for WP and PIW. Concerning, the effect of irrigation treatments on WP and PIW, data in Table (7) indicated that, the highest overall mean values for the two studied parameters were recorded under irrigation treatment $\mathrm{I}_{0}$ and the values are 3.26 and 2.31 $\mathrm{kg} / \mathrm{m}^{3}$ for WP and PIW, respectively. Meanwhile, the lowest values were recorded under irrigation treatment $I_{3}$ and the values are 2.79 and $1.98 \mathrm{~kg} / \mathrm{m}^{3}$ for WP and PIW, respectively.

Table (6): Effect of irrigation treatments and some micronutrients foliar application on water productivity WP $\left(\mathrm{kg} / \mathrm{m}^{3}\right)$ and productivity of irrigation water PIW $\left(\mathrm{kg} / \mathrm{m}^{3}\right)$ for fibers, calyxes, seeds yield / fed in the two seasons (2014-2015)

\begin{tabular}{|c|c|c|c|c|c|c|c|c|}
\hline \multirow[t]{2}{*}{ Treatments } & \multicolumn{4}{|c|}{ Water productivity $\left(\mathbf{k g} / \mathbf{m}^{3}\right)$} & \multicolumn{4}{|c|}{ productivity of irrigation water $\left(\mathrm{kg} / \mathrm{m}^{3}\right)$} \\
\hline & fibers & calyxes & Seeds & Whole plant & fibers & Calyxes & Seeds & Whole plant \\
\hline & \multicolumn{8}{|c|}{$1^{\text {st }}$ season } \\
\hline \multirow{4}{*}{$\begin{array}{l}\mathrm{I}_{0} \\
\mathrm{I}_{1} \\
\mathrm{I}_{2} \\
\mathrm{I}_{3}\end{array}$} & 2.21 & 0.49 & 0.88 & 3.58 & 1.56 & 0.35 & 0.62 & 2.53 \\
\hline & 2.01 & 0.44 & 0.75 & 3.20 & 1.43 & 0.31 & 0.53 & 2.27 \\
\hline & 1.77 & 0.25 & 0.56 & 2.58 & 1.26 & 0.18 & 0.40 & 1.84 \\
\hline & 1.89 & 0.30 & 0.71 & 2.90 & 1.34 & 0.21 & 0.51 & 2.06 \\
\hline \multirow{6}{*}{$\begin{array}{c}\text { Control } \\
\mathrm{Fe} \\
\mathrm{Zn} \\
\mathrm{Mn} \\
\mathrm{Fe}+\mathrm{Zn}+\mathrm{Mn} \\
\end{array}$} & 1.24 & 0.22 & 0.38 & 1.84 & 0.86 & 0.15 & 0.26 & 1.27 \\
\hline & 1.65 & 0.29 & 0.52 & 2.46 & 1.16 & 0.21 & 0.36 & 1.73 \\
\hline & 2.08 & 0.34 & 0.63 & 3.05 & 1.47 & 0.24 & 0.45 & 2.16 \\
\hline & 2.15 & 0.44 & 0.88 & 3.47 & 1.54 & 0.31 & 0.63 & 2.48 \\
\hline & 2.71 & 0.56 & 1.22 & 4.49 & 1.97 & 0.41 & 0.88 & 3.26 \\
\hline & \multicolumn{8}{|c|}{$2^{\text {nd }}$ season } \\
\hline \multirow{4}{*}{$\begin{array}{l}I_{0} \\
I_{1} \\
I_{2} \\
I_{3}\end{array}$} & 1.84 & 0.41 & 0.68 & 2.93 & 1.31 & 0.29 & 0.48 & 2.08 \\
\hline & 1.96 & 0.36 & 0.59 & 2.91 & 1.41 & 0.26 & 0.43 & 2.10 \\
\hline & 1.65 & 0.22 & 0.48 & 2.35 & 1.19 & 0.16 & 0.34 & 1.69 \\
\hline & 1.81 & 0.27 & 0.59 & 2.67 & 1.29 & 0.19 & 0.42 & 1.90 \\
\hline \multirow{5}{*}{$\begin{array}{c}\text { Control } \\
\mathrm{Fe} \\
\mathrm{Zn} \\
\mathrm{Mn} \\
\mathrm{Fe}+\mathrm{ZN}+\mathrm{Mn}\end{array}$} & 1.36 & 0.19 & 0.31 & 1.86 & 0.95 & 0.13 & 0.22 & 1.30 \\
\hline & 1.51 & 0.23 & 0.41 & 2.15 & 1.07 & 0.16 & 0.29 & 1.52 \\
\hline & 1.77 & 0.27 & 0.49 & 2.53 & 1.27 & 0.19 & 0.35 & 1.81 \\
\hline & 1.97 & 0.38 & 0.67 & 3.02 & 1.42 & 0.27 & 0.48 & 2.17 \\
\hline & 2.43 & 0.50 & 1.04 & 3.97 & 1.79 & 0.37 & 0.76 & 2.92 \\
\hline
\end{tabular}


Table (7): The overall mean value of water productivity WP $\left(\mathrm{kg} / \mathrm{m}^{3}\right)$ and productivity of irrigation water PIW $\left(\mathrm{kg} / \mathrm{m}^{3}\right)$ for fibers, calyxes, seeds and whole roselle yield plants in the two seasons

\begin{tabular}{|c|c|c|c|c|c|c|c|c|}
\hline \multirow[t]{3}{*}{ Treatment } & \multirow{2}{*}{\multicolumn{2}{|c|}{$\begin{array}{l}\text { The overall mean values } \\
\text { through the two seasons } \\
\text { fibers }\end{array}$}} & \multirow{2}{*}{\multicolumn{2}{|c|}{$\begin{array}{c}\text { The overall mean values } \\
\text { through the two seasons } \\
\text { Calyxes }\end{array}$}} & \multirow{2}{*}{\multicolumn{2}{|c|}{$\begin{array}{l}\text { The overall mean values through } \\
\text { the two seasons }\end{array}$}} & \multicolumn{2}{|c|}{$\begin{array}{l}\text { The overall mean values } \\
\text { through the two seasons }\end{array}$} \\
\hline & & & & & & & \multicolumn{2}{|c|}{ Whole roselle plant } \\
\hline & WP $\left(\mathrm{kg} / \mathrm{m}^{3}\right.$ & $\mathrm{PIW}\left(\mathrm{kg} / \mathrm{m}^{3}\right)$ & $W P\left(\mathrm{~kg} / \mathrm{m}^{3}\right)$ & $\operatorname{PIW}\left(\mathrm{kg} / \mathrm{m}^{3}\right)$ & $W P\left(\mathrm{~kg} / \mathrm{m}^{3}\right)$ & $\mathrm{PIW}\left(\mathrm{kg} / \mathrm{m}^{3}\right)$ & $W P\left(\mathrm{~kg} / \mathrm{m}^{3}\right)$ & $\mathrm{PIW}\left(\mathrm{kg} / \mathrm{m}^{3}\right)$ \\
\hline \multirow{4}{*}{$\begin{array}{l}\mathrm{I}_{0} \\
\mathrm{I}_{1} \\
\mathrm{I}_{2} \\
\mathrm{I}_{3}\end{array}$} & 2.03 & 1.44 & 0.45 & 0.32 & 0.78 & 0.55 & 3.26 & 2.31 \\
\hline & 1.99 & 1.42 & 0.40 & 0.29 & 0.67 & 0.48 & 3.06 & 2.19 \\
\hline & 1.71 & 1.23 & 0.24 & 0.17 & 0.52 & 0.37 & 2.47 & 1.77 \\
\hline & 1.85 & 1.32 & 0.29 & 0.20 & 0.65 & 0.47 & 2.79 & 1.98 \\
\hline \multirow{5}{*}{$\begin{array}{c}\text { Control } \\
\mathrm{Fe} \\
\mathrm{Zn} \\
\mathrm{Mn} \\
\mathrm{Fe}+\mathrm{Zn}+\mathrm{Mn}\end{array}$} & 1.30 & 0.91 & 0.21 & 0.14 & 0.35 & 0.24 & 1.85 & 1.29 \\
\hline & 1.58 & 1.12 & 0.26 & 0.19 & 0.47 & 0.33 & 2.31 & 1.63 \\
\hline & 1.93 & 1.37 & 0.31 & 0.22 & 0.56 & 0.40 & 2.84 & 1.99 \\
\hline & 2.06 & 1.48 & 0.41 & 0.29 & 0.78 & 0.56 & 3.25 & 2.33 \\
\hline & 2.57 & 1.88 & 0.53 & 0.38 & 1.13 & 0.82 & 4.23 & 3.09 \\
\hline
\end{tabular}

Regarding, the effect of micronutrients foliar application, the highest overall mean values were recorded under micronutrients foliar application ( $(\mathrm{Fe}+\mathrm{Zn}+\mathrm{Mn})$ comparing with other treatments and control and the values are 4.23 and $3.09 \mathrm{~kg} / \mathrm{m}^{3}$ for WP and PIW, respectively. But the lowest overall mean values were recorded under control treatment (without application and the values are 1.85 and $1.29 \mathrm{~kg} / \mathrm{m}^{3}$ for WP and PIW, respectively. Increasing the overall mean values for WP and PIW, under irrigation treatment $\mathrm{I}_{0}$ and micronutrients foliar application ( $(\mathrm{Fe}+\mathrm{Zn}+\mathrm{Mn})$ may be attributed to increasing yield under the conditions of these treatments in comparison with other treatments.

\section{Conclusion}

It can be concluded that skipping one irrigation at vegetative growth stage when cultivated roselle plants under studied region combined with chelated $\mathrm{Fe}+\mathrm{Zn}+\mathrm{Mn}$ foliar application which counteracted the deleterious effects of stress and chelated $\mathrm{Zn}$ foliar application only to increase chemical component. Nevertheless, reduction in yield offset saving nearly $9 \%$ of applied water.

\section{REFERENCES}

A.O.A.C. (2005) Official Methods of Analysis of the Association of Official Analytical Chemists $15^{\text {th }}$ Ed, Arlinton, Virginia USA.

Abd EL-Hady, BA (2007). Effect of Zinc Application on Growth and Nutrient Uptake of Barley Plant Irrigated with Saline Water. J. Appl. Sci. Res., 3(6): 431-436.

Abdalla, F.E; M, Zainab. M; and A.A. El-Sayed (1992). Effect of micronutrients foliar application on uptake of macronutrients by wheat and faba bean. Afr. J. Agric.Sci., 19(1): 181-192. 
Akbari,G.A; M. Amirinejad ; A, Baghizadeh ; I., Allahdadi and M., Shahbazi (2013). Effect of $\mathrm{Zn}$ and Fe Foliar Application on Yield, Yield Components and some Physiological Traits of Cumin (Cuminum cyminum, L) in Dry Farming. Int .J. Agr. PI.Pro. Vol., 4 (12), 32313237.

Ali, B.H.; N, Al Wabel; G, Blunden (2005). Phytochemical, pharmacological and toxicological aspects of Hibiscus sabdariffa, L.: a review Phytother. Res. 19: 369-375.

Ali, M.H., M.R. Hoque: A.A. Hassan and A. khair (2007). Effects of deficit irrigation on yield, water productivity and economic returns of wheat. Agricultural water management, 92 (3): 151-161.

Babaeian, M. ; I, Piri ;A, Tavassoli ;Y, Esmaeilian and H, Gholami (2011).

Effect of water stress and micronutrients (Fe, Zn and Mn) on chlorophyll fluorescence, leaf chlorophyll content and sunflower nutrient uptake in Sistan region. Afri. J. Agri. Res . 6(15): 3526-3531.

Bagci SA, Ekiz H, Yilmaz A, Cakmak I, (2007). Effects of Zinc deficiency and water stress on grain yield of field-grown Wheat cultivars in central Anatolia. Agronomy and Crop Science. 193: 198-206.

Bertamini, M; L, Zulini ; R, Zorer; K, Muthuchelian; and N, edunchezhian(2007). Photo inhibition of photosynthesis in water deficit leaves of grapevine (Vitis vinefera ,L.) plants Photosynthetica 45:426-432.

Cakmak, I (2000). Possible roles of Zinc in protecting plant cells from damage by reactive oxygen specious. New Phytol. 146: 185-205.

Curie, C andJ.F, Briat (2003) Iron transport and signaling in plants. Ann.Rev. Plant Biol., 54: 183-206.

Doorenbos, J. and W. O. Pruitt (1975). Crop water requirements. Irrigation and Drainage paper, No. 24, FAO Rome.

Du, C. T. and F. J., Francis (1973). Anthocyanins of roselle (Hibiscus sabdariffa, L). J. Food Sci., 38: 810-812.

Early, A.C. (1975). Irrigation scheduling for wheat in the Punjab. CENTO Scientific Programme on the optimum use of water in agriculture. Report No. 17, Lyallpur, Pakistan, 3-5: 115-127.

El-Boraie,F.M ; A.M, Gaber and G. Abdel-Rahman (2009). Optimizing Irrigation Schedule to Maximize Water Use Efficiency of Hibiscus sabdariffa under Shalatien Conditions. World Journal of Agricultural Sciences 5 (4): 504-514'.

El-Fouly ,M. M. ; M, Mobarak .Zeinab and A, Salama, Zeinab (2011) .Micronutrients ( $\mathrm{Fe}, \mathrm{Mn}, \mathrm{Zn}$ ) foliar spray for increasing salinity tolerance in wheat Triticum aestivum, L. Afri, J, PI, Sci. 5(5): 314-322.

Gao, W.R. ; X.S.H, Wang ; P, Liu; J.G, Li and H. Ma , Zhang( 2008). Comparative analysis of ESTs in response to drought stress in chickpea (Cicer arietinume, L.). Biochemical Biophysical Research Communications, 376: 578-583.

Grewall, H.S and R, Williams (2000). Zinc nutrition alfalfa response to water stress and excessive. Journal of plant nutrition. 23: 949-962.

Hajlaoui, H; H, Mighri; E, Noumi; M, Snoussi ; N, Trabelsi ; R, Ksouri and A, Bakhrouf (2010). Chemical composition and biological activities of Tunisian Cumin essential oil: a high effectiveness against Vibrio spp. Strains Food Chem Toxicol. 48: 2186- 2192. 
Hansen, V.W.; O.W. Israelsen and G.E. Stringharm (1979). Irrigation principles and practices. 9th ed., John Willey and Sons Inc., New York, USA.

Herrera-Arellano, A; S, Flores-Romerob ; M.A , Chávez-Sotoc and J, Tortoriello (2004). Effectiveness and tolerability of a standardized extract from Hibiscus sabdariffa , $L$ in patients with mild to moderate hypertension: a controlled and randomized clinical trial. Phytomedicine 11: 375-382.

Hussein, M.M; A. Safaa, Mahmoud and A.S, Taalab (2013). Yield and nutrient status of barley plant in response to foliar application of fertilizers under water deficit conditions. Journal of Applied Sciences Research, 9(7): 4388-4396.

Jackson, M.I (1973). Soil Chemical Analysis. Prentice Hall of India private, LTD New Delhi.

James, L. G. (1988). Principles of farm irrigation system design John Willey and Sons Inc., New York, S43.

Kassab, M.M. and M.A.M. Ibrahim (2007). Cut off wheat (triticum sp.) Irrigation as an effective technique for improving water management. Alex Sci. Exchange Jour, 28(4):158-167.

Kassab, O.M., (2005). Soil moisture stress and micronutrients foliar application effects on the growth and yield of mungbean plants. J. Agric. Sci., Mansoura University, 30: 247-256.

Kirby, R.H. (1963). "Vegetable Fibers" Nicholes Pullunin. Inter - Science ed. By Prof. Publish Inc. 129-131. New York.

Kirk, R.S. and R. Sawyer, (1997) Pearson's Composition and Analysis of Foods. 9th Ed. Longman, Singapore : 238-239.

Klute, A.C (1986). Water retention: laboratory Methods. In: A. klute (ed), Methods of Soil Analysis, part1 2nd (ed.) Agron Monogr.9, ASA, Madison, W1 U.S.A, pp. $635-660$.

Lavon, R.; R. Salomon and E.E. Goldschmidt (1999). Effect of potassium magnesium and calcium deficiencies on nitrogen constituents and chloroplast components in citrus leaves. J. Amer. Soc. Hort. Sci, 124: 158-162.

Mafakheri, A.; B. Siosemardeh; P.C. Bahramnejad andY. Sohrabi,( 2010). Effect of drought stress on yield, proline and chlorophyll contents in three chickpea cultivars. Australian Journal of Crop Science,4(8):580-585.

Maheshwari, B.L and H.S, Grewal (2009) Magnetic treatment of irrigation water : its effects on vegetable crop yield and water productivity. Agric. Water .Manage.96:1229-1236.

Mazrou, M. M.; Afify, M. M.; Wahba, H. E.; Mohamed, M. A.; Eraki, M. A. and Mahfouz, S. (2002). Effect of irrigation and upper grad on growth, yield and chemical composition of roselle plant. Faculty of Agriculture Menofiya University, Shibin El-Kom, Egypt Bulletin of the National Research Center. Cairo, 2002; 27 (4): 533-548.

Meowad, A. A.; Fiad, A. M. and M. M. Hafez (2005). Effect of irrigation interval treatments on growth yield, anthocyanin production and some chemical constituents of roselle plants under sandy soil and drip irrigation system conditions. Zagazig J. Agric. Res. 32 (2): 441-454.

Moursi, E. A.; Manal, A. Aziz and Mona, A. M. El-Mansoury (2014). Effect of length of irrigation run and nitrogen rates on productivity of some 
wheat cultivars, some water relations and nitrogen content in heavy clay soil. J. Agric. Res. Kafr El-Sheikh Univ., 40 (3): 630-658.

Movahhedy-Dehnavy, M.M; S.A.A, Modarres-Sanavy and A, MokhtassiBidgoli (2009). Foliar application of zinc and manganese improves seed yield and quality of safflower (Carthamus tinctorius L.) grown under water deficit stress. Ind. Cro, Pro. (30):82-92.

Nabizadeh ,E; M, Banifazel and E, Taherifard (2012). The effects of plant growth promoting on some of traits in maize (cv. S.C.704 ) under drought stress condition. Euro. J. Exp. Bio, 2 (4):875-881.

Naguib, Y.N; M.S, Hussein ; S.E, El-Sherbeny ; M.Y, Khalil and D, Lazari (2007) .Response of Ruta graveolens, L. to sowing dates and foliar micronutrients.J. App. Sci. Res, 3(11): 1534-1543.

Nasiri,Y ; S, Zehtab-Salmasi; S, Nasrullahzadeh ; N, Najafi and K, GhassemiGolezani (2010). Effects of foliar application of micronutrients (Fe and $\mathrm{Zn}$ ) on flower yield and essential oil of chamomile (Matricaria chamomilla L). Jour. Med. PI . Res. 4(17): 1733-1737.

Ngouajio, M ; G, Wang and R., Goldy ( 2007).Withholding of drip irrigation between transplanting and flowering increases the yield of fieldgrown tomato under plastic mulch. Agric .Water Manage. 87, 285291.

Pinstrup-Andersen, P; R , Pandya-Lorch and M.W , Rosegrant (1999). World food prospects, Critical issues for the early twenty-first century, 2020 Vision Food Policy Report, International Food Policy Research Institute, Washington, D.C.

Rashed, Nahed, M and E. A. Moursi (2012). Influence of cultivation method and irrigation regime on growth, oil yield and some water relations of sage (Salvia officinalis, L.) in heavy clay soil. Alex. Science Exchange Journal Vol. 33. No 2.

Rehm, G and S ,Albert (2006)Micronutrients and Production of Hard Red Spring Wheat. Minnesota Crop News. March 7: 1-3.

Said-Al Ahl ,H.A.H and Mahmoud, A(2010). Effect of zinc and / or iron foliar application on growth and essential oil of sweet basil (Ocimum basilicum ,L.) under salt stress. Oz. J. App.Sci. 3: 97-111.

Sajedi, N.A; M.R. Ardakani; A, Naderi; H. Madani and A.B.M, Mashhadi (2009). Response of Maize to Nutrients Foliar Application under Water Deficit Stress Conditions. Am. J. Agric. Bio. Sci. 4(3): 242-248.

Shao,H; S, Jiang; F, Li; L, Chu; C, Zhao; M, Shao; X, Zhao and F, Li(2007) Some advances in plant stress physiology and their implications in the system biologyera Bio interfaces54:33-36.

Sidky, M. H.; M. R. Hoque; A. A. Hassan and A. Khair (2007). Effect of deficit irrigation on yield, water productivity, and economic returns of wheat Agricultural Water Management, 92 (3): 151-161.

Soha, E. Khalil and Rabie, M. M. Yousef (2014). Interaction effects of different soil moisture levels, Arbuscular Mycorrhizal Fungi and three phosphate levels on: 1- growth, yield and photosynthetic activity of Garden Cress (Lepidium sativum , L.) plant. International Journal of advanced Research (2014), Vol. 2 Issue 6, 723-737.

Steel, R.G. and Torrie, J.H (1980). Principles and Procedures of Statistics, MC. Graw Hill Book Company Inc. New York (N.L.S.D.), London.

Thalooth, A. T., M. M. Tawfik and H. Magda Mohamed (2006). A comparative study on the effect of foliar application of zinc, potassium and some 
chemical constituents of Mungbeen plants grown under water stress conditions. World Journal of Agricultural sciences 2 (1): 3746.

Wajid, A.; A, Hussain; A, Wajid; A. A, Hussain; A, Ahmed; M, Rafiq; A.R, Goheer and M, Ibrahim (2004). Effect of sowing date and plant density on growth, light interception and yield of wheat under semiarid condition. Intl. J.Agric. Biol., 6: 1119-1123.

Wang, $\mathrm{H}$ and J.Y, Jin (2005). Photosynthetic rate, chlorophyll fluorescence parameters and lipid per oxidation of maize leaves as affected by zinc deficiency. Photo. Syntetica. 43: 591- 596.

Waraich, E.A; R. Ahmad; Saifullah; M. Y, Ashraf ; Ehsanullah(2011). Role of mineral nutrition in alleviation of drought stress in plants. Aust. J. Cro. Sci. 5(6):764-777.

Younis, S. I.; E. A. Moursi; F. R. Moussa and Shalaby, I. A. (2009). Effect of irrigation intervals on the yield and quality of roselle plants (Hibiscus Sabdariffa, L.) under drip irrigation in heavy clay soils. J. Biol. Chem. Environ. Sci. Vol. 4 (1): 589-605.

Zaki, Nabila .M; G, Ahmed, Amal; H, Mohamed, Magda .H; M.M, Tawfik and M.S, Hassanein (2013) Effect of skipping one irrigation and potassium fertilization on growth and yield of chickpea plants. World Applied Sciences Journal 27 (5): 557-561.

Zehtab-Salmasi, S; F, Heidari and H, Alyari (2008). Effects of microelements and plant density on biomass and essential oil production of peppermint (Mentha piperita L.).PI. Sci. Res. 1: 24-26

$$
\begin{aligned}
& \text { الملخص العزبي }
\end{aligned}
$$

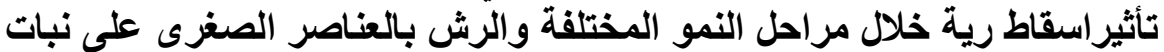

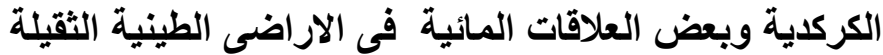

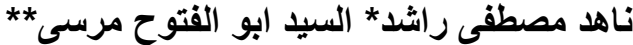

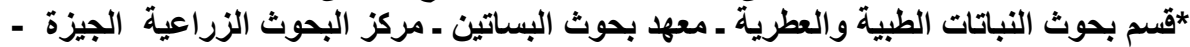

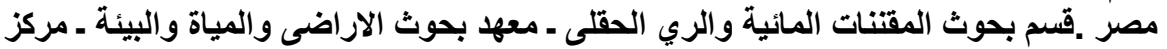

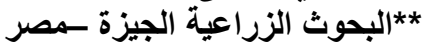

تعتبر المياه هى العنصر الأكثر أهمية في الحياة، وسر عان ما أصبحت سلعة نادرة

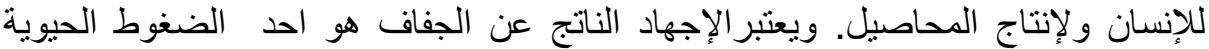

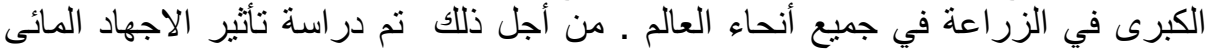

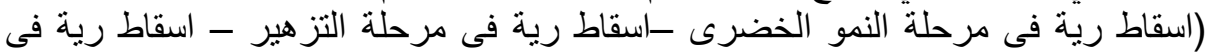

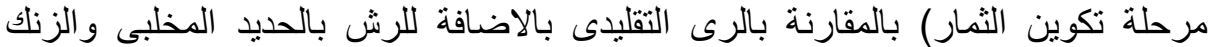

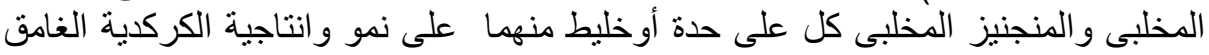

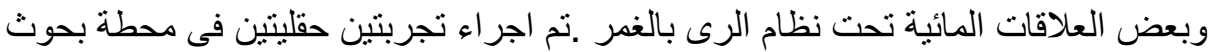

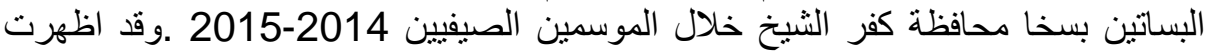

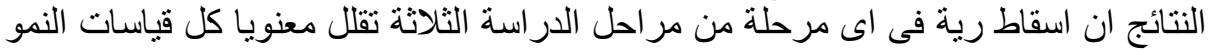

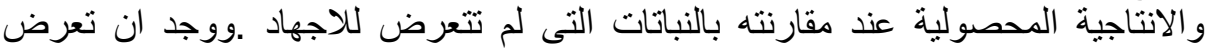

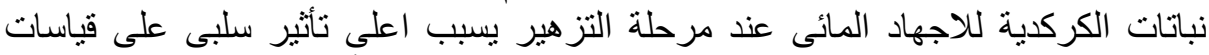

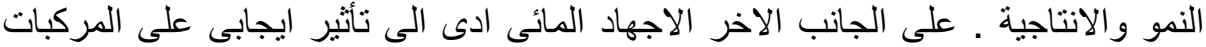




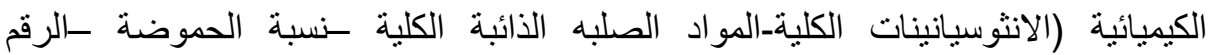

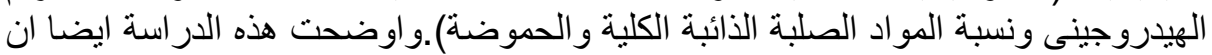

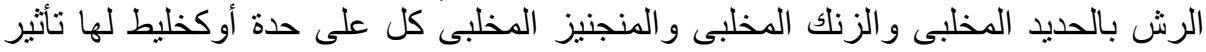

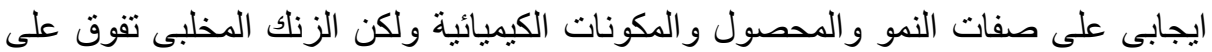
باقى العناصر فى تقليل الاثر الضار للاجهاد على المكونات الكيميائية.ادى الرش الرئ بالحديد

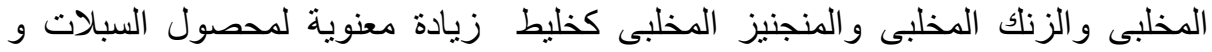
الالياف و البذور للفدان .ووجد ان اقل ماء مضاف ولك وماء مستهلك عند معاملات الاجهاد

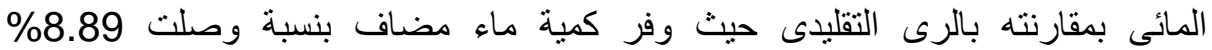
بينمااعلى انتاجية لوحدة المياه المستهلكة واعلى النتاجية لوحدة المياه المضافة لوفية لمحصول

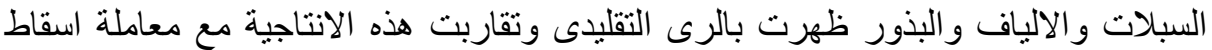

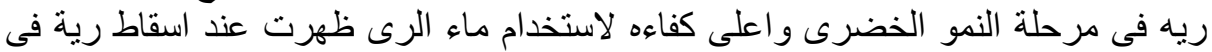

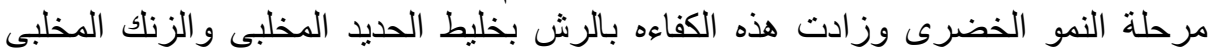

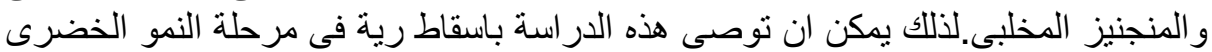

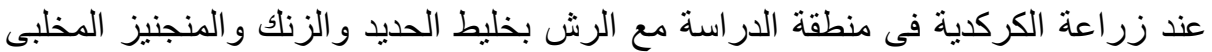

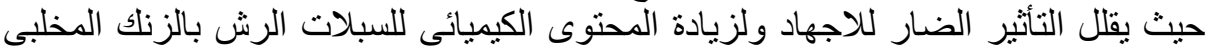

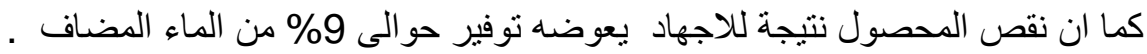

